Florida International University

FIU Digital Commons

FIU Electronic Theses and Dissertations

University Graduate School

$11-5-2020$

\title{
The Bolivarian Dream: ALBA and the Cuba-Venezuela Alliance
}

Victor Lopez

Florida International University, vlope115@fiu.edu

Follow this and additional works at: https://digitalcommons.fiu.edu/etd

Part of the International and Area Studies Commons

\section{Recommended Citation}

Lopez, Victor, "The Bolivarian Dream: ALBA and the Cuba-Venezuela Alliance" (2020). FIU Electronic Theses and Dissertations. 4573.

https://digitalcommons.fiu.edu/etd/4573

This work is brought to you for free and open access by the University Graduate School at FIU Digital Commons. It has been accepted for inclusion in FIU Electronic Theses and Dissertations by an authorized administrator of FIU Digital Commons. For more information, please contact dcc@fiu.edu. 


\title{
FLORIDA INTERNATIONAL UNIVERISTY
}

Miami, Florida

THE BOLIVARIAN DREAM: ALBA AND THE CUBA-VENEZUELA ALLIANCE

\author{
A thesis submitted in partial fulfillment of the \\ requirements for the degree of \\ MASTER OF ARTS \\ in \\ INTERNATIONAL STUDIES \\ by \\ Victor Lopez
}

2020 


\section{To: Dean John Stack}

Steven J. Green School of International and Public Affairs

This thesis, written by Victor Lopez, and entitled The Bolivarian Dream: ALBA and the CubaVenezuela Alliance, having been approved in respect to style and intellectual content, is referred to you for judgment.

We have read this thesis and recommend that it be approved.

Jorge Duany

Eduardo Gamarra

Astrid Arrarás, Major Professor

Date of defense: November 5, 2020

The thesis of Victor Lopez is approved.

Dean John Stack

Steven J. Green School of International and Public Affairs

Andres Gil

Vice President for Research and Economic Development and Dean of the University Graduate School

Florida International University, 2020 
ABSTRACT OF THE THESIS

THE BOLIVARIAN DREAM:

ALBA AND THE CUBA-VENEZUELA ALLIANCE

by

Victor Lopez

Florida International University, 2020

Miami, Florida

Professor Astrid Arrarás, Major Professor

This thesis seeks to answer why the Bolivarian Alliance for the Peoples of Our America (ALBA) has failed to achieve its two major goals: to create a socialist alternative to neoliberalism and foster mutual cooperation among the members. Important constructivist works from Nicolas Onuf and Alexander Wendt were used throughout. Emphasis is given to the debate between social construction and material reality that has hindered ALBA's goals.

Three reasons led to why ALBA could not achieve its two major goals. First, the successors to the founding leaders of ALBA were less persuaded by the organization's ambitious goals, and instead carved their own foreign policy. Second, ALBA did not create a socialist alternative since its programs were plagued by ill-defined rules. Third, China, Iran, and Russia, were pulled to ALBA due to the influence of Venezuela. These actors related to ALBA members on a bilateral basis, which hurt ALBA's mutual cooperation. 


\section{TABLE OF CONTENTS}

CHAPTER

PAGE

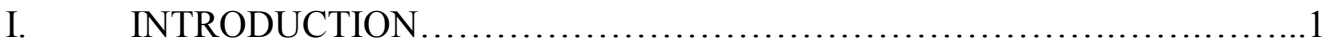

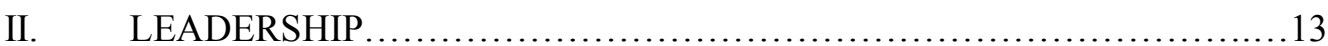

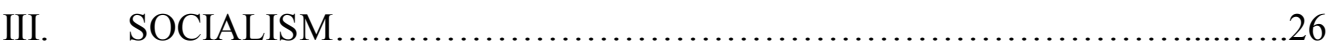

IV. DIVERGENCE...................................................49

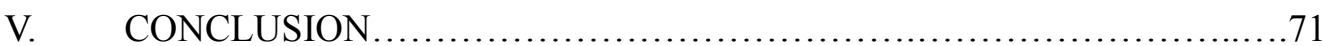

BIBLIOGRAPHY .............................................................. 


\section{CHAPTER I INTRODUCTION}

Many states in Latin America desire to create an identity independent of the United States (U.S.) and its political and economic influence. Cuba and Venezuela attempted to defy the U.S. with an organization called the Bolivarian Alliance for the Peoples of Our Americas (ALBA, for its Spanish acronym) in 2004. Other countries joined ALBA shortly. ALBA had two major objectives: (I) to create a socialist alternative to neoliberalism, and (II) to foster cooperation.

This thesis will argue that ALBA failed to achieve these objectives for three reasons. First, the change in leadership of the founding member states of ALBA, Cuba and Venezuela, with the rise of Raúl Castro and Nicolás Maduro, weakened the support for ALBA. These leaders were less persuaded by ALBA's goals. Second, ALBA did not become a socialist alternative to neoliberalism. Many of the socialist programs from ALBA were ill-defined and did not lead to sustainable development. Third, non-regional states caused tensions among ALBA members. I also highlight the impact of the changing leadership of some of the member states, in their perception of ALBA. Venezuelan leaders welcomed assistance from China, Iran, and Russia. However, they only made bilateral agreements where few members benefited.

This thesis consists of five chapters. In the first chapter, I will briefly review the literature on constructivism in international relations. Additionally, I will provide a background on the origins of ALBA. In the second chapter, I will examine the change of leadership in Cuba and Venezuela. A third chapter will analyze how ALBA did not become a socialist alternative to neoliberalism. A fourth chapter will examine how non-regional assistance was welcomed by Venezuela and was not multilateral. The change in leadership among ALBA members resulted in weakening cooperation will be discussed in detail. The final chapter provides a summary.

\section{A World of Our Making}

My analysis of ALBA begins with constructivism, a theory that privileges the roles of actors, ideas, and material reality in international relations. I begin with the seminal work by Nicholas Onuf because it describes some of the essential constructivist elements. One of the most 
important is that ideas and aspects of social reality can be debated, and the intricate relationship between rules and rulemaking. These theoretical discussions are important since they provide a reference regarding the role of leadership and the rules that are developed.

Onuf begins his analysis by suggesting that in constructivism, people and society construct, or constitute, each other. ${ }^{1}$ Reality therefore is a social construction. This also implies that science is to a degree a social construction because theories, observations, and data have cognitive and physical limitations. However, knowledge is not completely made in our heads. For him, the act of constructing makes history. In history, people are reconstructing history or condemning it. ${ }^{2}$ Consequently, people may also celebrate it. Essentially, many aspects of society, such as science, knowledge, and history are social constructions since people have different interpretations and cognitive limitations that impact how they perceive ideas and knowledge.

For Onuf, rules are an issue of language, and not fact. Rules are social since people can weigh the costs and benefits of obeying or disobeying. Additionally, rules become conventional through repetitive speech action, where certain speech can turn agreed principles into action. Speeches that emphasize assertiveness, affirmation, and conviction lead direction for rulemaking. Furthermore, such language directs people's actions, which Onuf calls directive rules. ${ }^{3}$ Rules turn to conviction once leaders decide to focus on making the decision public and becomes an obligation. The conviction becomes duty when the rule-maker promises to act. ${ }^{4}$ Onuf concludes that in the battle for influence, the state leadership resort to strategies to control symbols,

\footnotetext{
${ }^{1}$ Nicholas Onuf, World of Our Making: Rules and Rule in Social Theory and International Relations (Columbia: University of South Carolina Press, 1989), 36.

${ }^{2}$ Onuf, World of Our Making, 39-40, 42-43.

${ }^{3}$ Ibid., 80-81, 86-87.

${ }^{4}$ Ibid., 88.
} 
violence, and material values. Moreover, leaders often exchange promises to obtain concessions. As a result, leaders who are persuasive can receive their desired concessions. ${ }^{5}$

Similar to how Onuf provided a theoretical foundation around the topic of social construction, rules and rulemaking, Wendt offers a discussion about the influence of leaders' beliefs and perceptions of the world and how it affects their desires and actions. Wendt further expands on the ideas of Onuf by providing a lengthy discussion of the role of structures in society. This is particularly important since in structures, leaders can debate ideas.

For Alexander Wendt, what largely constitutes interests are ideas. Therefore, ideas and culture have more impact on state action than most actors might believe. ${ }^{6}$ Wendt suggests that beliefs play a role in state actions. What matters is that state leaders have a belief of how the international system works. Consequently, what matters is that state leaders hold their beliefs to be valid and act on it. Beliefs help to facilitate state leaders to act to fulfil their desires. ${ }^{7}$ In constructivism, belief is about the world and where state leaders perceive their place, while desire is about state leaders trying to change the international system to conform to their views. ${ }^{8}$

While all states in the international system have a desire for stability, some states may act to defend other states. Wendt labels these countries as collectivist states because their leaders have a zealous belief to defend their friends and act morally. ${ }^{9} \mathrm{He}$ insinuates that a substantial amount of state action can best be explained by the ideas that guide them. Therefore, power and security are important because of the ideas that construct them. In society, when leaders legislate and enforce their policies, the policies and actions can be traced back to societal and cultural

\footnotetext{
${ }^{5}$ Ibid., 228, 257.

${ }^{6}$ Alexander Wendt, Social Theory of International Politics (Cambridge: Cambridge University Press, 1999), 114-115.

${ }^{7}$ Wendt, Social Theory of International Politics, 117-118.

${ }^{8}$ Ibid., 119.

${ }^{9}$ Ibid., 125.
} 
interaction as well as the belief system of the leadership. ${ }^{10}$ As a result, international relations is equally influenced by agency, structure, and culture, and not just the leaders of different states. ${ }^{11}$

In constructivism, ideas are not the only area of focus; structures are also important. Wendt argues that structures in the international system have three basic parts: ideas, interests, and material conditions. All three parts are interconnected. ${ }^{12}$ In this debate, the distribution of knowledge matters a great deal. Knowledge may be divided into two parts: private knowledge and shared knowledge, or culture. In private knowledge, the actor has beliefs and values that are not known to other actors and is derived from ideological and domestic considerations. When states interact, their private knowledge becomes distributed to other actors. Shared knowledge, or culture, includes norms, values, and ideas that people have in common. ${ }^{13}$

Wendt continues by suggesting that common knowledge is personal because beliefs are internal. Common knowledge exists only in the heads of actors and beliefs can change. Wendt emphasizes that collective knowledge matters to the extent that it is different for each actor and changes. Ideas and concepts become different based on the actors' perceptions. ${ }^{14}$

Constructivism is helpful for several reasons. First, it privileges that rulers have a near monopoly on rulemaking power and can lead society to adopt certain regulations. In the case of Raúl Castro and Nicolás Maduro, this is important because both leaders had to adjust a foreign policy that was extremely idealistic and unsustainable. More important, both leaders had to modify the rules guiding their countries because Raúl and Maduro needed international recognition to survive. Second, both leaders decided to pullback from full support for ALBA

\footnotetext{
${ }^{10}$ Ibid., 135-136.

${ }^{11}$ Ibid., 138.

${ }^{12}$ Ibid., 139.

${ }^{13}$ Ibid., 140-141.

${ }^{14}$ Ibid, 161-162.
} 
because they were contending with challenging domestic and foreign politics: Maduro had to deal with popular resistance in his country, and Raúl wanted Cuba to be less dependent on Venezuela. ${ }^{15}$ From the constructivist view, this makes sense because both leaders could not ignore material reality and had to change their foreign and domestic situation to survive.

Since ALBA was founded on a socialist ideology, constructivism can help to explain why the organization failed in becoming an alternative to neoliberalism. First, part of the issue revolves around Cuba's foreign policy, internationalism, a significant human development project that was unmatched in other countries. Since ALBA had a basis of reciprocity, Cuba would contribute by providing professionals, but some other members could not offer just compensation. These countries gave Cuba raw materials, such as food, as payment for professional services. This was ultimately unsustainable. Second, in Venezuela, Maduro had to contend with domestic opposition to the government's socialist-inspired policies. He also could not relate to the people on an emotional level and easily persuade many Venezuelans to embrace socialism. This is possible because Cuba and Venezuela experienced a disconnect between ideas and reality.

Another issue that challenged ALBA was that Venezuela welcomed relationships beyond the region. From a constructivist view, this is evident because Venezuela's ruling elite felt secure if it allied with Iran, Russia, and China. Also, the extra-regional states wanted bilateral relationships. Concurrently, Honduras, Ecuador, and Bolivia all left the organization and dealt a blow at the legitimacy of the organization. The issue is that many of the members decided to carve their own foreign policy, and compromised cooperation. However, the new rulers in those countries felt threatened by socialism and perceived that a foreign policy change was in their best interest. This results from the fact that ideas and material reality are not in sync. In constructivism, material reality cannot be ignored, and it often has more of an effect on leaders and policies than ideas, beliefs, values, and cultural sympathies.

${ }^{15}$ Carlos Romero, "Cuba and Venezuela," in Cuban Foreign Policy: Transformation under Raul Castro, ed. H. Michael Eirsman and John M. Kirk (Lanham: Rowan \& Littlefield, 2018), 220. 


\section{Limitations and Contribution}

One significant limitation to the thesis is that I chose to not use a dominant international relations theory. One theory that challenges my analysis is neorealism. In particular, I will discuss the main argument that John Mearsheimer argues in his book, The Tragedy of Great Power Politics. Mearsheimer argues that in the international system, the threat of war looms large and states consistently compete for power. ${ }^{16}$ The competition does not subside until a state achieves hegemony, and states will look for an opportunity to change power in their favor. Mearsheimer believes that three factors in the international system cause states to behave in an aggressive manner. ${ }^{17}$ First, there is no central authority to protect states. Second, states have an offensive military capability, and third, states are never sure of each other's intentions. States, therefore, are in a constant struggle for power, where self-survival is paramount. ${ }^{18}$ For Mearsheimer, a multipolar system is particularly dangerous because it lacks a hegemon. States that have the military capability to engage a war of attrition against a potential hegemon are dangerous. Also, states that have nuclear weapons are also dangerous for the international system. ${ }^{19}$

Neorealism offers a great challenge for my case because it may be argued that ALBA was created solely as a mechanism to balance the U.S. and neoliberalism. It may be also argued that Iran, Russia, and China have engaged in ALBA to exclusively balance the United States. These assertions are true. It is correct to assert that the ALBA is working toward creating a multipolar system where the U.S. is not the hegemon. The argument I provide is different, because the main argument concerns with the role of ideas and material reality. Constructivism is

\footnotetext{
${ }^{16}$ Mearsheimer, John, The Tragedy of Great Power Politics (New York, London: W.W. Norton \& Company, 2001), 2.

${ }^{17}$ Mearsheimer, The Tragedy of Great Power Politics, 2-3.

${ }^{18}$ Ibid, 3.

${ }^{19}$ Ibid, 5.
} 
the better theory to analyze ALBA because the organization was founded on the ideals of socialism and organizational cooperation. Ideas are important because they motivate leaders to inspire action. Yet, ideas are also limited by material conditions, such as geography, inequality, and discrimination among other issues. How people interact is in constant change, and that interaction helps to guide developments in the international system. Neorealism does not provide that type of analysis. Neorealism is concerned with power dynamics and hegemonic potential. There is little discussion about ideas and even less discussion about different aspects material conditions in society. Consequently, constructivism is the best theory of choice to discuss why ALBA failed to achieve its two major goals. Neorealism does offer a great challenge to constructivism, but my analysis is concerned with ideas and material conditions, which is where constructivism has a significant comparative advantage over neorealism.

The discussion I provide for the failure of ALBA to achieve its two major goals is important for constructivism for several reasons. First, my thesis explores the importance of socialism as an influence for ALBA. Socialism is the guiding idea that allows for the ALBA leaders to create an identity and organization that challenges U.S. influence in Latin America and the Caribbean. Second, the thesis shows how socialism has allowed for ALBA to attempt to control is material reality. As a result, I provide extensive detail regarding the difficulties that ALBA faced when changing their material reality and how the socialist programs did not achieve sustainable economic and human development. Third, by using the major theoretical works by Onuf and Wendt, I display how the ideas and material reality of ALBA was incongruent and the impact the incongruency had on the implementation of their socialist ideals.

In the analysis provided in this thesis, I believe that the most important factors to be discussed are the impact of the changing leadership of the ALBA members, and the reality that the ALBA programs did not achieve meaningful cooperation. These factors are equally important because they illustrate how the ideas of the ALBA members changed with new leadership. More important, my thesis shows how different domestic and international issues have compelled the 
new leaders to assess the ALBA alliance and what their new foreign policy should be. This is in line with constructivist theory, especially the battle between ideas and material reality. The implementation of the ALBA programs is also important because it highlights the problems that ALBA had in promoting and encouraging cooperation among its member. In particular, a discussion of the People's Trade Agreement, Unified Regional Compensation System, and Petrocaribe shows how the ALBA members were not easily persuaded by these programs. More important, most of these programs were filled with rules and regulations that were ill defined. Equally important, the programs were loaded with socialist rhetoric that did not provide concrete measures to achieve some of its lofty goals. The third factor discussing the relationship between Iran, Russia, and China is given less importance because these states showcase the weakness of cooperation among the ALBA members. Additionally, these alliances were not persuaded ALBA's socialist struggle. This is important because it highlights how material reality limits the ideas of leaders despite their attempts otherwise. Overall, this thesis provides a great case for constructivist theory and to show how the socialist ideals were challenged by material reality.

\section{Our People}

One of the foundations of ALBA is Cuba's foreign policy, known as internationalism. The success of such foreign policy depends on several factors, including conviction to socialism and international solidarity. ${ }^{20}$ For naming purposes, the professionals that Cuba exports are called internationalists. The internationalists are sent to states that lack basic services a nd where socialism can be spread. In this sense, the internationalists are not just professionals; they help the less fortunate because of their overzealous beliefs in socialism and altruism. ${ }^{21}$

\footnotetext{
${ }^{20}$ Danielle Benzi and Ximena Zapata, "Good-Bye Che? Scope, Identity, and Change in Cuba's SouthSouth Cooperation," in South-South Cooperation Beyond the Myths: Rising Donors, New Aid Practices? ed. Isaline Bergamaschi, Phoebe Moore, and Arlene B. Tickner (London: Palgrave Macmillan, 2017), 89.

${ }^{21}$ Benzi and Zapata, "Good-Bye" 90.
} 
The internationalist foreign policy follows some of the suppositions made by Onuf. First, rules come as a mandate from the leadership. ${ }^{22}$ In Cuba, Fidel dictated that the professional services that were exported had to espouse and display the best aspects of socialism. This also satisfies Cuba's other goals, such as improving the island's economy and obtaining diplomatic recognition. ${ }^{23}$ Second, rules also allow for the government to designate certain roles for citizens. When rules have formal actors, they solidify the likelihood of certain rules to be followed. ${ }^{24}$ Fidel wanted to turn Cuba into a medical capital, and virtually all aspects of professional life equated to defending socialism. As a result, Cuba regarded cooperation as a way to preach socialism. ${ }^{25}$

In 1999, after the Vargas State mudslide in Venezuela, Cuba attempted its largest international assistance program by sending internationalists to Venezuela to assist its citizens. This was the start of a strategic partnership between the two states, where Venezuela would send oil to Cuba in exchange for professional services, mostly medical. ${ }^{26}$ Subsequently, in 2004 , ALBA was created by Cuba and Venezuela. Both states wanted to deepen their cooperation, and desired to include other members. ${ }^{27}$ States such as Bolivia, Nicaragua, Ecuador, and various Caribbean islands joined ALBA. The main signatories, Cuba and Venezuela, agreed to exchange various goods and services. This was most evident in the humanitarian assistance provided by Cuba, known as missions, which covered many types of assistance, including medical. ${ }^{28}$

\footnotetext{
${ }^{22}$ Onuf, World of Our Making, 138-9.

${ }^{23}$ Benzi and Zapata, "Good-Bye" 82-84.

${ }^{24}$ Onuf, World of Our Making, 140-1.

${ }^{25}$ Benzi and Zapata, “Good-Bye” 89-90.

${ }^{26}$ Ibid, 96.

${ }^{27}$ Ibid, 96.

${ }^{28}$ Max Azicri, "The Cuba-Venezuela Alliance and Its Continental Impact," in Cuba in a Global Context: International Relations, Internationalism, and Transnationalism, ed. Catherine Krull (Gainesville: University Press of Florida, 2014), 127, 129.
} 
Among the first missions was Misión Milagro, where Cuban nurses, physicians, dentists, and technicians were sent to the rural and poor areas of Venezuela to provide medical care. Other internationalists were given tasks in administration, logistics, and agriculture. The economic benefits for Cuba were exceptional. As a result of the trade with Venezuela, the internationalists were the single most profitable aspect of the Cuban economy. ${ }^{29}$ Essentially, Cuba's internationalism kept the state afloat amidst the dangerous international system.

Misión Milagro was a success in the region. As a result of the mission, millions of people received free medical services and eye care. However, José Briceño-Ruiz, in his chapter, notes various contradictions about how many people received medical care. The extent of Venezuela's leading role in Misión Milagro became questionable. For example, Briceño-Ruiz doubts whether medical equipment was transferred from Cuba for Venezuela's own use. In some instances, Venezuela had to send patients to Cuba for treatment. ${ }^{30}$

To return to constructivism for a moment, Wendt offers a useful discussion of structure and its relation to actors. For Wendt, some material factors do affect politics, but that institutions become a pool of ideas. ${ }^{31}$ The Bolivarian government decided to promote a multilateral international system, and one way to do so was to partner with Cuba. To achieve it, Chávez decided to promote Misión Milagro, and cover the transportation costs of the Cuban doctors. ${ }^{32}$

This fulfils Wendt's thesis that institutions and systems of government are ultimately ideational. He argues that socialism becomes comparable to capitalism since both economic systems are based on theory and mixed with some cultural discussions. Socialism becomes

\footnotetext{
${ }^{29}$ Azicri, “The Cuba-Venezuela Alliance and Its Continental Impact," 96-97.

${ }^{30}$ José Briceño-Ruiz, "Venezuela and South-South Cooperation: Solidarity or Realpolitik?" in South-South Cooperation Beyond the Myths: Rising Donors, New Aid Practices? ed. Isaline Bergamaschi, Phoebe Moore, and Arlene B. Tickner (London: Palgrave Macmillan, 2017), 182.

${ }^{31}$ Wendt, Social Theory of International Politics, 96.

32 Jose Briceño-Ruiz, “Venezuela and South-South Cooperation: Solidarity or Realpolitik?” 182-183.
} 
constructed on material causes that allowed the idea to form. ${ }^{33}$ Misión Milagro fulfils this since Chávez saw that Venezuela lacked basic health services for its marginalized groups.

Many Venezuelans feared the loss of employment opportunities. While Cuba initially sent their internationalists to attend to humanitarian efforts, it evolved into a reformation of the Venezuelan health system. The initial plan was for Cuban internationalists to train their Venezuelan professional counterparts. However, this did not occur, and many Cubans stayed in Venezuela. Cuban doctors were paid impoverished salaries, and the Cuban government was aggressive to note that their aid to Venezuela was cooperation. Benzi and Zapata showed that actions such as these would undermine ALBA. For example, Cuban internationalists often told their Venezuelan patients that the island was not a paradise. Internationalists often brought merchandise back to the island as compensate for the poor salaries. ${ }^{34}$

Internationalism, therefore, has weaknesses that constructivism can explain. For Wendt, international relations are affected by material factors, most notably through the material capabilities of states, the types of material goods states possess, and natural resources, and physical location. Materials influence actors because ideas cannot overcome material challenges. More important, while people can change politics, they cannot change geography, natural resources, and material constraints. ${ }^{35}$ In Cuba, the material reality is that professionals are underpaid. Consequently, the internationalists took the opportunity to bring back various goods. ALBA has clearly faced several practical problems. These range from the actual number of Venezuelans who have received Cuban healthcare to the near impoverished life that internationalists live. Overall, many of the patients were grateful for the treatment they received. ${ }^{36}$

\footnotetext{
${ }^{33}$ Wendt, Social Theory of International Politics, 94-96.

${ }^{34}$ Ibid., 97-99.

${ }^{35}$ Wendt, Social Theory of International Politics, 110-2.

${ }^{36}$ Ibid., 97.
} 
Questionable is, how many people were treated because of the humanitarian missions? BriceñoRuiz mentions that 3,470,206 people were treated through Misión Milagro. ${ }^{37}$ However, João Marcello Furtado and his co-authors mention that the number of people treated by Misión Milagro was much smaller. Their report shows that 157,000 Venezuelans received cataracts treatment. However, caution should be taken because Furtado notes that patients who were blind was unknown, and people who were not blind received treatment. ${ }^{38}$

As a result of Barrio Adentro, infant mortality fell from 19 to 13.9 deaths per 1000 live births, and post neonatal mortality decreased from 9.0 to 4.2 deaths per 1000 live births in Venezuela. Additionally, the average Venezuelan life span increased by one and a half years between 2000 and 2009. By 2009, more than $80 \%$ of Venezuelans were consulted and treated by doctors. ${ }^{39}$ Due to Barrio Adentro, the poverty rate decreased from $62.1 \%$ to $31.5 \%$ from 2003 to 2008. Furthermore, the income gains for the Venezuelan lower classes were remarkable. The lower 80 and $90 \%$ of the population made more income gains than the upper classes between 1998 and 2006. The humanitarian projects were ambitious because Chávez wanted to provide his country free health care, education, housing, sports and recreation, food, and work-training. ${ }^{40}$

To compensate Cuba for its humanitarian assistance, Venezuela decided to provide the island with oil. Following the signing of the ALBA agreement in December 2004, Chávez directed the Venezuelan state oil company Petroleos de Venezuela, S.A. (PDVSA) to supply the island with 200,000 barrels per day. Since ALBA is a multilateral organization, member states could pay for the oil with raw materials such as food. ${ }^{41}$

\footnotetext{
${ }^{37}$ Ibid., 182.

${ }^{38}$ João Marcello Furtado, et al., "Is Misión Milagro an effective program to prevent blindness in Latin America?” Arq Bras Oftalmol 73, 5 (August 2010): 397.

${ }^{39}$ Steve Brower, Revolutionary Doctors: How Venezuela and Cuba are changing the World's Conception of Health Care (New York: Monthly Review Press, 2011), 92.

${ }^{40}$ Brower, Revolutionary Doctors, 79-80.

${ }^{41}$ Azicri, “The Cuba-Venezuela Alliance and Its Continental Impact,” 128.
} 


\section{CHAPTER II LEADERSHIP}

In this chapter, I will discuss the role of Raúl Castro and Nicolás Maduro, the leaders of Cuba and Venezuela respectively, and their decisions to place less emphasis on ALBA. Raúl served as Cuba's president from 2008-2018, while Maduro was elected as President of Venezuela in 2013, and continues in power today, although his presidency has been disputed since 2019 . Through a constructivist approach, I plan to show that Raúl and Maduro were less persuaded by ALBA's goals than their predecessors, Fidel Castro and Hugo Chávez, and decided to focus their energy on other important issues, such as diplomacy, domestic stability, and development.

\section{Raúl Castro}

In 2006, Fidel underwent surgery and handed power temporarily to his brother, Raúl. One of Fidel's major foreign policy successes was his friendship with Chávez, especially since both were espousing a revolutionary conviction. ${ }^{1}$ Under Raúl's direction, Cuba signed various military agreements with Chávez that allowed Cubans to join the high ranks of the Venezuelan military. Additionally, Raúl helped to enhance Venezuela's military and political intelligence. ${ }^{2}$ Once Chávez passed away and Maduro assumed leadership, Raúl signed 57 agreements with the new Venezuelan government, which increased the number of Cubans working in electricity, education, health, agriculture, and sports projects in Venezuela. The agreements allowed for 6,000 more Cuban workers to go to Venezuela. As a result, anger toward Cubans began to increase, prompting Raúl to argue that the Venezuelan political opposition was to blame. ${ }^{3}$ In 2014, 640 Cuban medical professionals defected to Colombia and other countries, and the number increased in 2015 to 720 . However, this did not appear to affect Raúl, because in

\footnotetext{
${ }^{1}$ John Kirk, "Historical Introduction to Foreign Policy under Raul Castro," in Cuban Foreign Policy: Transformation under Raul Castro, ed. H. Michael Eirsman and John M. Kirk (Lanham: Rowan \& Littlefield, 2018), 2, 9.

${ }^{2}$ Carlos Romero, "Cuba and Venezuela," in Cuban Foreign Policy: Transformation under Raul Castro, ed. H. Michael Eirsman and John M. Kirk (Lanham: Rowan \& Littlefield, 2018), 212.

${ }^{3}$ Romero, “Cuba and Venezuela,” 215-216.
} 
2015 he visited Caracas to celebrate the achievements made with Venezuela, including the number of hospitals and clinics built, as well as literates taught. Raúl added that the relationship with Venezuela had problems, especially because the U.S. sanctions against Maduro had complicated Maduro's efforts to support the alliance. In 2016, Raúl proclaimed that Cuba would continue to support Venezuela. ${ }^{4}$ Equally important, he noted that barriers hampered the relationship with Venezuela, such as the impoverished Cuban economy. ${ }^{5}$

Raúl focused on increasing Cuba's presence in Latin America by directing foreign policy toward other states in the region. ALBA originally was an intergovernmental alliance between Fidel and Chávez, and Raúl believed that Cuba would benefit from stronger relations with other countries in the region. ${ }^{6}$ Thus, Raúl was not looking out for ALBA, only for the island. In the regional agreements, Raúl wanted the island to benefit from cooperation toward infrastructure, energy, and security. Social issues, therefore, were not the main priority for him. ${ }^{7}$ Raúl decided to better Cuba's relationship with Brazil and Mexico. Under the governments of Lula da Silva, Dilma Rousseff, and Michel Temer, Cuba increased trading with Brazil. As a result, between 2003 and 2013, Brazil became the third most important trading country for the island, following China and Venezuela. However, under the direction of Temer, Brazil reduced the number of Cuban doctors received and relations with Venezuela became difficult to manage. ${ }^{8}$

In contrast, due to its geography, many of Mexico's public officials are constantly thinking about the strategic moves of the U.S. and its impact on trade. Additionally, Mexico also aspired to become closer with its Latin American allies. In 2012, Mexican voters elected Enrique

\footnotetext{
${ }^{4}$ Ibid., 217-219.

5 Ibid., 219.

${ }^{6}$ Andrés Serbín, "Cuba and Latin America and the Caribbean," in Cuban Foreign Policy: Transformation under Raúl Castro, ed. H. Michael Eirsman and John M. Kirk (Lanham: Rowan \& Littlefield, 2018), 82-83.

${ }^{7}$ Serbín, "Cuba and Latin America and the Caribbean," 83.

${ }^{8}$ Ibid., 85-86.
} 
Peña-Nieto, a businessman friendly to the United States. Both Peña-Nieto and Raúl decided to initiate bilateral trade agreements to increase trade and cooperation between Mexico and Cuba. Consequently, Mexico became the seventh largest destination of Cuban doctors and medical personnel. Mexico also became Cuba's largest trading partner in Latin America after Venezuela and Brazil. Furthermore, Mexican companies could operate in Mariel, Cuba's free trade zone. ${ }^{9}$ Raúl wanted to reduce Cuba's dependence on Venezuela and ALBA, which is why he decided to pursue ties with Brazil, Mexico, and the United States. In Latin America, Raúl developed a new foreign policy: "circular" foreign policy. In this new direction, Cuba would focus on its immediate circle, which were Latin American countries that were part of the New Left movement. Many of the New Left governments, such as Hugo Chávez, Lula da Silva, Dilma Rousseff, and Cristina Fernández de Kirchner were sympathetic to the island. More important, many of the New Left leaders were not anti-American, and Raúl believed that he could use those countries to develop a better relationship with the United States. Therefore, having a warm relationship with the U.S. would give the Cuban government a better image in the region. ${ }^{10}$

\section{A Constructivist Approach to Raúl's Actions}

As Onuf mentions throughout his book, a key component of constructivism is deeds, where speech leads to action. Our world, to continue, is in constant flux because discourse is always changing. Hence, knowledge is also changing due to the fact because peoples' social positions differentiate over time. ${ }^{11}$ For Raúl, the situation with Venezuela worsened during the 2010s, while the political attachment to the Chávez/Maduro regime was hurting the island. Raúl was primarily concerned with his country's economic growth and believed an alliance with the U.S. would help him. More important, he needed the money from remittances, U.S. imports and

\footnotetext{
${ }^{9}$ Ibid., 87.

${ }^{10}$ Ibid., 79, 84, 89-90.

${ }^{11}$ Onuf, World of Our Making, 37, 40.
} 
perhaps investments, and tourism to keep the economy afloat. Venezuela could not provide any of that because Maduro faced a vocal domestic opposition that disturbed the Bolivarian project. ${ }^{12}$ Equally important, the medical internationalism project began to show signs of deterioration. In many countries, the island was not compensated for its medical services. For example, in Brazil, the governments of Rousseff and Temer were unable to persuade more Brazilian doctors to join the Mais Medicos program. Cuba offered 11,430 medical professionals and Brazil could not match. Additionally, Cuba charged different rates per country based on the ability to repay the island. Since many countries in the region are poor, Cuba could not easily find new markets. ${ }^{13}$ As Wendt suggests, political interest and power are not completely ideational, and have some material factors that alter them. He argues that while institutions have ideational heritage, they ultimately cannot be divorced from the culture that help form them. ${ }^{14}$ More important, how an actor perceives the world is a result of their culture and their ideas. ${ }^{15}$ In the case of Raúl, this is important, because he assumed power after the official end of the Cold War, when the island had recovered from the aftermath of the demise of the Soviet Union. Cuba needed economic rejuvenation, and Raúl believed that economic stability could be achieved by partnering with other Latin American and Caribbean states, not solely Venezuela. Ideationally, Raúl was still a socialist, but he did not want to repeat what happened when the Soviet Union collapsed and caused a disruption for Cuba. Materially, Raúl wanted to continue to export professionals across the world and to ALBA and allow the island to obtain material goods and services.

Wendt also argues that ideas are important because they help to determine state interests. As a result, institutions become important because they allow for actors to persuade other actors

\footnotetext{
${ }^{12}$ Romero, "Cuba and Venezuela," 210.

${ }^{13}$ Kirk, "The Evolution of Cuban Medical Internationalism," 62-63, 65.

${ }^{14}$ Wendt, Social Theory of International Politics, 95-96.

${ }^{15}$ Ibid., 137-138.
} 
of their ideas, and to influence material reality. Therefore, in institutions, leaders desire to impact knowledge where they can spread their ideas. ${ }^{16}$ Moreover, a similar pattern is shown in culture, where people share knowledge that eventually becomes accepted in that society, including rules, beliefs, and values. ${ }^{17}$ In the case of Cuba, Raúl decided to change some of the accepted ideas, especially that shared values could not be the decisive factor in initiating economic or diplomatic relations. Raúl believed that Cuba was limiting itself if it placed too much energy into ALBA and saw that better relations with other countries might be better. This meant that Raúl was going to be careful as to which state would he work with. Allying with the U.S., for instance, was done out of economic necessity. Raúl understood that the island could not fight the U.S. for eternity, so he paved the path for a better relationship. Again, Cuban public officials remained loyal to socialism, but Raúl was willing to put political beliefs aside in exchange for economic ventures. In this respect, constructivism shows that while ideas help shape actors and institutions, actors cannot escape that material reality influences ideas. While Venezuela provided a great market for Cuba's internationalists and reciprocated with oil, the island could not solely depend on the Maduro government for economic assistance. As has been mentioned, Venezuela was an outlet for internationalists to defect, especially since in Venezuela they could still buy necessities to survive. In Cuba, people could barely survive while in Venezuela they could live a comfortable life. It is a material reality that Venezuela could offer a lot for Cuba, especially the oil subsidies. Yet, the internationalists could purchase goods and services that were hard to come by on the island. Consequently, while Cuba may have impressive human capital, the underlying material economic factor is that Venezuela has oil and could pay the Cuban government for its professional services. Material reality influenced Raúl to keep and maintain the Venezuelan alliance, despite the fact that Cuba needed to diversify its international alliances.

\footnotetext{
${ }^{16}$ Ibid., 139-140.

${ }^{17}$ Ibid., 141.
} 


\section{Nicolás Maduro}

In October 2012, Chávez won his last election. Between then and his death in March 2013, his successor would be largely decided in Cuba, guided by Fidel and Raúl. The Castro brothers negotiated a pact between Nicolás Maduro, then the Venezuelan foreign minister; Diosdado Cabello, the former National Assembly president; and Rafael Ramírez, the former president of PDVSA and energy minister. In January 2013, the Havana Pact was signed, where Maduro was selected as Chávez’s successor, and Cabello and Ramirez would play supporting roles to keep domestic stability. ${ }^{18}$ Maduro was a strategic choice that benefited Cuba. He was foreign minister from 2006-2013 and worked to ensure that international pressure would not force Venezuela to change within. Venezuela was well regarded in the international system and almost no country openly challenged Chávez. Other states were interested in securing the Maduro transition. Former Colombian president Juan Manuel Santos, for example, planned to have peace talks with the Revolutionary Armed Forces of Colombia (FARC) to end decades of violence. Santos also wanted Venezuela to be involved in the peace process. Brazil supported Maduro as well. Exports from that country to Venezuela increased and commercial ties became stronger. China became another country whose support was critical in the transition. Under Chávez, Venezuela became a market for Chinese investment and development projects. ${ }^{19}$

In foreign policy, Maduro inherited from Chávez the dispersion of raw materials, especially petroleum, the emergence of new powers in the international system, and the continued reorientation of U.S. policy toward the Middle East. As a result of high oil prices, Venezuela could send oil all over the world. However, when Maduro assumed power, oil prices dropped, and he received no help from Middle East allies. Moreover, Brazil and Russia, two major

\footnotetext{
${ }^{18}$ Corrales and Penfold, Dragon in the Tropics: The Legacy of Hugo Chávez (Washington, DC: Brookings Institution Press, 2015), 158, 161, 163-164.

${ }^{19}$ Ibid., 164-165.
} 
economic supporters of Venezuela, faced economic sanctions from the U.S. that reduced assistance to Maduro. In addition, the U.S. placed sanctions against Maduro, which allowed him to become more radical and consolidate domestic support. ${ }^{20}$ Maduro attached himself to a foreign policy that was carried over from Chávez and was dependent upon certain circumstances such as high oil prices, strong support from ALBA, Brazil, Russia, and China. ${ }^{21}$

Another issue that Maduro faced was the questioning of his legitimacy as leader. During his tenure, oil prices decreased, and the opposition made gains in the National Assembly. The intricate domestic and foreign policy system created by Chávez worked largely because he was charismatic and could count on widespread popular support. Chávez received the support of various marginalized groups. Chávez was also close to the Cuban government and many leftist governments. Maduro, however, was not charismatic. ${ }^{22}$ As foreign minister, Maduro spent most of time visiting other countries and gaining external allies for Venezuela. He hardly knew the Venezuelan people and their challenges and had little knowledge of domestic affairs. ${ }^{23}$

Maduro developed his reputation as the head diplomat for Venezuela. Therefore, his actions affected both the international system and his diplomatic agency. In this process, agents and structures influenced how foreign policies were formulated. The process is constructivist because agents share their ideas and discuss their historical circumstances, and the different cultures that agents hold influence their decisions. As a result, beliefs and cultures that are internalized by agents are more difficult to change in the international system. ${ }^{24}$ Maduro best

\footnotetext{
${ }^{20}$ Carlos Romero and Víctor Mijares, "From Chavez to Maduro: Continuity and Change in Venezuelan Foreign Policy," Contexto Internacional (January/April 2016): 187-189.

21 Romero and Mijares, "From Chavez to Maduro," 188-190.

22 Ibid., 191-192.

${ }^{23}$ Corrales and Penfold, Dragon in the Tropics, 161.

${ }^{24}$ Wendt, Social Theory of International Politics, 313-315.
} 
exemplifies this since he is a member of Venezuela's socialist party, together with former leader Chávez. However, Maduro also shows signs that he is not adapting to the changes in the international system. For example, beginning in 2014, oil prices dropped, and his ability to influence the system was significantly reduced.$^{25}$ As Wendt argues, in the international system, agents interact with each other to sustain their concepts of other and self. The international system becomes a venue for more interaction between agents, and sometimes identities change as a result. Wendt continues by suggesting that identities are the result of interaction, which becomes a process to maintain the international system. ${ }^{26}$ Maduro created his own identity because he was Chávez's foreign minister and longest tenured during this regime. The basic framework of Maduro's foreign policy was carried over from Chávez, which was to destabilize U.S. hegemony and allow Venezuela to become a pillar in a multilateral system. At the same time, the foreign policy did not work with Maduro because he could not identify with most of the Venezuelan citizenry. His foreign policy was concerned with maintaining ties with New Left leaders, and especially the alliance with Cuba. To circumvent the domestic opposition, Maduro has relied on media outlets to propagandize the international system with the Bolivarian Revolution's ideals. ${ }^{27}$ Maduro's foreign policy is further complicated by the domestic opposition, which uses various free speech outlets to publicize the problems of his regime. ${ }^{28}$ Romero and Benayas argue that agents began to focus on leaders' ability to protect their state. They perceive that leaders are likely to increase the use of media to help influence their foreign policy and international position. ${ }^{29}$ Maduro, therefore, used the Bolivarian Revolution to contest U.S. leadership and to

\footnotetext{
${ }^{25}$ Romero and Mijares, "From Chavez to Maduro," 166-167.

${ }^{26}$ Wendt, Social Theory of International Politics, 316.

${ }^{27}$ Romero and Mijares, "From Chavez to Maduro," 166, 174-175.

${ }^{28}$ Ibid., 176.

${ }^{29}$ Carlos Romero and Grecia Benayas, "Venezuela: el ocaso de una democracia," Revista Mexicana de Ciencias Políticas y Sociales, no. 233 (February 2018): 292-293.
} 
become a leader in deciding the price of oil. The domestic opposition has been critical of Maduro for ignoring democratic principles and isolating the country from its democratic neighbors. ${ }^{30}$ It is evident that the interaction between agents within Venezuela and abroad matters a great deal. While Maduro has been able to maintain the basic framework of the Bolivarian Revolution, he has contended with an international environment that is not conducive to the expansionist foreign policy that he desired to achieve. His foreign policy and international position are contested because many Latin American states are allied with the U.S., especially under President Donald Trump, and a new alliance, the Lima Group, is openly challenging Maduro. ${ }^{31}$

\section{Constructing Maduro}

Returning to the work of Onuf, he argues that in politics there are a group of people called the influentials that have control over how people create, invent, and exchange value. ${ }^{32}$ What is important for a leader is to use speech and language to convey and perform action. Moreover, the reason why language is important is because it engages the different material senses through the way the leaders engage and animate in speeches and action. Consequently, leaders who are great communicators are more likely to get their message spread and likely to initiate action in the public. ${ }^{33}$ When looking at the case of Maduro, he fulfils some of these requirements. Maduro benefited from his previous position as foreign minister for Chávez and was able to become one of his close allies. This helped Maduro gain two essential skills. First, he gained trust from the socialist party and became a staunch advocate for party doctrine. Second, as foreign minister, he was able to both represent himself and Chávez. Therefore, when Maduro was

\footnotetext{
${ }^{30}$ Romero and Benayas, "Venezuela: el ocaso de una democracia," 296-297.

${ }^{31}$ Ibid., 301-302.

${ }^{32}$ Onuf, World of Our Making, 230.

${ }^{33}$ Ibid., 236.
} 
chosen as the successor to Chávez, few leaders in the region challenged the decision. However, Maduro was not influential in several aspects. One must consider that when Chávez died, the opposition embraced political violence. This highlighted the fact that political divisions in Venezuela were becoming much starker in the post-Chávez era. Homicide and crime were increasing as well. ${ }^{34}$ Many Venezuelans publicly expressed their growing fears and concerns.

This raises the question: What caused the people of Venezuela to be afraid? As Luis Angosto- Ferrández views the situation, he argues that Maduro was not influential. AngostoFerrández suggests that an influential leader, and also a moral entrepreneur, is at the right place in the right time to put their beliefs into action. Chávez was influential because he placed the marginalized people at the center of his political agenda. He wanted to ignite progressive change. Since the Bolivarian Revolution was tied to social progress, Chávez translated his domestic struggle into a global struggle in his foreign policy. ${ }^{35}$ In contrast, Maduro was unable to win the confidence of the Venezuelan people. Additionally, Maduro was not charismatic or goodhumorous as Chávez was. Moreover, he suggests that Maduro was unable to obtain an alliance system of likeminded leaders. For Angosto-Ferrández, countries such as Bolivia and Nicaragua were not likeminded allies because their leaders had different ideological and constitutional systems. ${ }^{36}$ Onuf helps to clarify this by arguing that influence partly involves shifting positions of value, such as rewards and advantages. Consequently, a ruler is given influence through authority ${ }^{37}$ If we return to the case of Maduro, he came to power because of a deal that was

\footnotetext{
${ }^{34}$ Michael Humphrey and Estrela Valverde, "Hope and Fear in Venezuelan Democracy: Violence, Citizen Insecurity, and Competing Neoliberal and Socialist Urban Imaginaries," in Democracy, Revolution, and Geopolitics in Latin America: Venezuela and the International Politics of Discontent, ed. Luis Fernando Angosto- Ferrández, (New York: Routledge, 2015) 147.

${ }^{35}$ Luis Fernando Angosto- Ferrández, "Ordering Discontent: Domestic and International Dynamics of the Bolivarian Revolution," in Democracy, Revolution, and Geopolitics in Latin America, 178, 186-187.

${ }^{36}$ Luis Fernando Angosto- Ferrández, “Ordering Discontent,” 177, 185.

${ }^{37}$ Onuf, World of Our Making, 237-238.
} 
negotiated by the Castro brothers. However, the domestic opposition saw an opportunity to challenge the Bolivarian government. He was outside the country for many years as the foreign minister and did not spend much time in the country.

From a constructivist view, the case of Maduro involves a battle for ideas. One of the largest problems is that the Castro brothers selected Maduro as the new leader of Venezuela. The Castro brothers took the initiative to select a leader whom they believed would keep the status quo. Therefore, it is unsurprising that Maduro faced domestic opposition. Equally important, Maduro was stuck in a situation where he received little consent from the Venezuelan people but significant support from the international community, at least until the contested 2019 elections.

\section{Conclusion}

Raúl Castro differed in many ways from his brother Fidel. For Raúl, providing medical assistance to many states did not result in a good return on investment. While Fidel was convinced of the moral virtues of the Revolution, Raúl realized that providing assistance based on ideology alone might not have been the best economic decision. Consequently, while some ALBA members were ideologically close to Cuba, their governments lack the funds for just compensation. Furthermore, during Raúl's tenure, Cuba witnessed the fall of Venezuela under Chávez and Maduro. Due to this reality, Raúl decided it was best for Cuba not to rely exclusively on Venezuela and ALBA, and instead focus on improving the island's international position.

As president, Raúl was able to direct the government to have a better relationship with other states. The relationship with the U.S. is significant since Raúl used it as an opportunity to get closer to the other Latin American states that were U.S. allies. Furthermore, the U.S. was the hegemon in the hemisphere, and he wanted the island to be under the good graces of the U.S. and not to be burdened by international condemnation. This was to balance Venezuela, which called into question as to whether the island could rely on it for economic and political support. Therefore, in a constructivist manner, Raúl changed the dialogue that Cuba was having with Venezuela. No longer was the discussion primarily about revolutionary ideals. Instead, the 
conversation became about how Cuba would benefit economically and politically from ALBA and the subsequent alliance with Venezuela. Consequently, ALBA did not appear to be an important issue for Raúl since it was not in line with his agenda. Moreover, once officially selected as president, Raúl did not have political restraint from his brother to stick to the old agenda, which was to support ALBA and its members economically and politically.

In summary, the objectives of Raúl Castro were unique. He perceived that Cuba's heavy dependence on ALBA and Venezuela would do more harm than good. Using his position of authority, he believed that the island should move away from ALBA and toward other states to help improve the country's economic and political position. This was most evident when Raúl decided to pursue relations with the United States. Under Raúl's leadership, Venezuela and other ALBA members still received doctors, but it became clear that he did not want this to continue forever. Furthermore, the change in Venezuela's domestic politics lead Raúl to reconsider that total economic and political dependency was not ideal for either country. Simply put, Raúl was a pragmatist who wanted Cuba to diversify its alliance beyond ALBA.

Nicolás Maduro faced a dangerous situation throughout his tenure as the new leader of Venezuela since 2013. While Chávez was the leader, Maduro was a member of the socialist party and became foreign minister. Consequently, he spent most of his time traveling the world and creating alliances to improve Chávez's position internationally. However, this worked against Maduro because he was not familiar with the internal dynamics within the country. More important, he was unaware of the struggles of the poorest citizens. When Chávez was ill, it was not the Venezuelan citizens who chose the successor, but Cuba's leaders. From a constructivist approach, several problems that should be noted. First, Maduro was in dialogue with various international leaders, and he depended on their support when he assumed power. Second, the Pact signed in Cuba showed how divided the Venezuelan government was. It seemed to work well when Chávez was healthy, but Maduro did not bridge the divisions that existed within the 
country. Third, Maduro won some support because he continued many of Chávez's agenda. However, once the price of oil dropped, Maduro could no longer justify the Chávez policies. In terms of ideas, Maduro has fallen short. The Castro brothers carefully selected an individual whom they believed would not challenge Cuba's leadership in ALBA and would continue to support the export of internationalists in the organization. Consequently, Maduro continued the policies of Chávez. When Maduro came to power, he had to answer why certain policies did not work. Furthermore, since Venezuela is one of the central leaders of ALBA, if it fell, so would the organizational projects. Without a strong Venezuelan leadership, ALBA falls apart. From the constructivist perspective, one must realize that ideas are unable to turn into action unless the material situations are in place. The public officials gave little consideration about how to solve the Venezuela domestic crisis or how to reorganize ALBA so that not all members do not have to depend on Venezuela. 


\section{CHAPTER III SOCIALISM}

As mentioned in the previous chapter, ALBA was a collaborative social project initiated by Fidel Castro and Hugo Chávez, and its existence essentially depended on their leadership. Once both leaders left, their successors, Raúl Castro and Nicolás Maduro respectively, did not share the same passion for the project. Consequently, both Raúl and Maduro faced a changing international order that was not friendly to the ALBA project and forced the leaders to change their foreign policy trajectories. In this chapter, I will discuss the first major objective of ALBA: to create a socialist alternative to neoliberalism. First I will discuss the shared beliefs of Fidel and Chávez as they pertain to international solidarity. Next will be a discussion of the different ALBA initiatives. In the conclusion, I assess the basic findings of my study and how they relate to ALBA failing to provide a socialist alternative to the U.S.-led system.

Fidel and socialism

Any discussion of ALBA must include the role and impact of Fidel Castro, the former dictator of Cuba. During his 47-year dictatorship, one of Fidel's greatest accomplishments was the island's medical internationalism. For Fidel, internationalism began in 1959, when he directed that Cuba's universities be open to the campesinos (farmers) for enrollment and provide them with employment opportunity. Education was fundamental to the Revolution. Fidel preached that internationalism includes sharing resources and providing strong relationships with other poor countries. Cooperation and altruism were part of the Cuban identity, dating back to the island's independence war. Moreover, Fidel taught Cubans that to provide humanitarian and cooperative assistance was to support the Revolution and internationalism. Therefore, internationalism was essential for Cuban patriotism. Fidel sent hundreds of doctors to other countries for humanitarian missions. In May 1960, Fidel sent the first internationalists to Chile, following an earthquake. He believed it was an opportunity to improve the island's relationship with Chile. Between 1961 and 1962, Cuba sent arms to Algeria to support a socialist insurgence. Fidel sent 15 nurses, 3 dentists, 
and 29 doctors to Algeria. In the first wave of internationalism, Cuba sent doctors to Africa and Asia, assisting those who revolted against European powers. ${ }^{1}$

Cuba helped graduate thousands of foreign medical students. In the 1987-88 school year, 1,523 foreign doctors graduated in Cuban medical schools and in the 1990-91 school year, 3,587 medical specialists graduated. Cuba has argued that Global South cooperation is essential to the island's survival, and part of the cooperation involved Cuban doctors visiting rural areas abroad. Many of these areas lacked the facilities to help out doctors. Yet, this was not a deterrent for them, because in 1991, one thousand Cuban doctors were working abroad. ${ }^{2}$ Between 1998 and 2004, Namibia had 2,863,313 Cuban doctor visits, and they gave 3,887,129 vaccinations. In Ghana, Cuba reported 1,748,815 pediatrician visits, and 68,637 surgeries. The Latin American Medical School in Havana was instrumental in the training of doctors from Central America. Between 2004 and 2005, Honduras enrolled 711 students and Guatemala enrolled 697. Preference was given to poor students, who were expected to practice in their local communities upon returning to their countries of origin. ${ }^{3}$ One goal of internationalism was to help sustain the health of poor people across the world, particularly in Africa and Latin America.

During the $21^{\text {st }}$ century, internationalism changed. The focus was no longer on providing medical professionals, training, and care to developing countries, but now included attention to physical and hearing disabilities, visual impairment, mental health, and intellectual disabilities. Cuban health professionals learned to record the problems that affected patients, including violence, alcohol abuse, natural disasters, malnutrition, and poverty, among others. The internationalists were part of a mass project that was supported by local medical professionals,

\footnotetext{
${ }^{1}$ John Kirk, Healthcare Without Borders: Understanding Cuban Medical Internationalism (Gainesville: University of Florida Press, 2015), 18-21.

${ }^{2}$ Kirk, Healthcare Without Borders, 26, 29.

${ }^{3}$ Ibid., 31-33.
} 
military and government personnel, and civilians. Since Cuban internationalists had to attend to the multiple problems of their patients, they needed substantial assistance. ${ }^{4}$

Fidel's internationalism was not only associated with exporting professional service, it was also aggressive toward the U.S. and imperialism. His antiimperialist beliefs could be traced back to José Martí. In his essay, "Nuestra América," Martí argued that regional disputes and focus on political realities and historical differences would affect the ability of Latin America to counter U.S. imperialism. In other writings, Martí feared that the U.S. would use different pretexts to intervene in Latin America. Fidel internalized the teachings of Martí, as a tool to defend the island against the United States. Much of what the Revolution involved was against the U.S., including the seizure of U.S. property, nationalizing private property, starting a literacy campaign, and seeking Soviet assistance. Most of all, the Revolution inspired other revolutions in Latin America, and this further solidified Martí's dream of an independent Latin America. ${ }^{5}$ As one may gather, Fidel was invested in the success of the export of professionals and the Revolution. Fidel desired to prove to the world that Cuba could defy the U.S. by exporting health professionals to which ever country needed it, and this helped to build ties in the Middle East, Asia, Africa, and Latin America. Consequently, Fidel became a larger than life figure and very few places today have not been impacted by the island's health professionals.

Overall, Fidel's political philosophy was a mixture of extreme belief in the Revolution, support for poor people around the world, and a conviction in equality of countries. His internationalist foreign policy supported these measures, and further emphasized Cuban characteristics, such as cooperation and altruism. Consequently, Fidel created a foreign policy

\footnotetext{
${ }^{4}$ Ibid., 70-72.

${ }^{5}$ Tim Anderson, "Chávez and American Integration," in Democracy, Revolution, and Geopolitics in Latin America: Venezuela and the International Politics of Discontent, ed. by Luis Fernando Angosto-Ferrández (London and New York: Routledge, 2014), 19-21.
} 
that allowed him to take advantage of the good nature of the Cuban people alongside his conviction to international solidarity and extremely sympathetic support to developing countries.

Chávez and the Bolivarian Social Project

The role of Chávez in ALBA cannot be underestimated, since he was the leader who took the organization's success personally. Angosto-Ferrández described Chávez as a moral entrepreneur, which is a person who is in the right place at the right time to cement their beliefs in an organization. ${ }^{6}$ This description certainly fits Chávez, as it illustrates how his personal attachment to changing Venezuela allowed him to also change Latin America and the Caribbean. Following will be a discussion of Chavez's involvement in health care and education.

According to Javier Corrales and Michael Penfold, the government that Chávez created was a hybrid of democracy and authoritarianism. In Chavismo, the military was visibly present in the government, and the Chávez officials were involved in managing the economy. The government was involved in many economic sectors, including telecommunications, electricity, hotels, and construction. More important, under Chávez, Venezuela's nationalized oil industry would lose significant revenues. Additionally, Chavismo involved the use of state resources to combat political opposition, and checks and balances vanished. Due to institutional weakness across various sectors of the country, important economic services eroded. Chávez treated the oil industry as a source of social charity and did not correct the industry's institutional weaknesses. ${ }^{7}$

In 1998, when Chávez was elected, 17 million Venezuelans lacked access to health care, and half of the population lived in poverty. More important, the country had a shortage of

\footnotetext{
${ }^{6}$ Luis Fernando Angosto-Ferrández, “Ordering Discontent: Domestic and International Dynamics of the Bolivarian Revolution, in Democracy, Revolution, and Geopolitics in Latin America: Venezuela and the International Politics of Discontent, ed. by Luis Fernando Angosto-Ferrández (London and New York: Routledge, 2014), 182.

${ }^{7}$ Corrales and Penfold, Dragon in the Tropics, 1-2, 7-8, 10.
} 
doctors. ${ }^{8}$ In the $1990 \mathrm{~s}$, most of the medical graduates either left the country or went into private practice, leaving only about 4,000 doctors to attend to the public service needed. This changed in 2002, when Chávez decided to offer public health services to the poor people, where only 29 doctors were participating. That year, two thousand Cuban doctors came to help with the Barrio Adentro mission. Many of the Venezuelan doctors detested working in the barrios, claiming that the people living there lacked hygiene, and the neighborhoods were dangerous. ${ }^{9}$ Additionally, the same doctors thought it was beneath them to work and live in the barrios. Cuban doctors, however, were shocked by the low quality of life in the country. They had to use many of the same techniques learned in third world countries in Africa and Asia. Despite these challenges, Chávez directed the construction of consultation offices and dispersal of doctors across the barrios. By 2009, 6,233 Cuban doctors worked in the barrios and 1,642 Venezuelans had completed their residency in the barrios. In 2003, Venezuela only had 2,371 dentists working in the public sector, and in 2009, the number dropped to 2,084. At that time, the dentists were working with more patients than in 2003. In 2004, 35 technology centers and 600 rehabilitation centers were built. Much of Barrio Adentro was initially a success because Chávez focused on having primary care in the barrios but did not attend to providing and improving hospital infrastructure. Furthermore, there was no single hospital system in the country. ${ }^{10}$

The educational policy that Chávez instituted followed the philosophy of Simón Bolívar, the $19^{\text {th }}$ Century Venezuelan leader who believed that enlightenment and morality were the foundation for a perfect government. Bolívar argued for an education that would deter people from idleness, selfishness, and negligence of other citizens. He also argued that education should lead to greater happiness for the rest of society. In the 1990s, education was largely privatized in

\footnotetext{
${ }^{8}$ Brower, Revolutionary Doctors, 75-76.

${ }^{9}$ Ibid., 75, 81-82.

${ }^{10}$ Ibid., 82, 86-89.
} 
Venezuela, and most citizens were denied access because of income, race, and/or social class. To address this, Chávez launched Misión Sucre, which targeted university education access. In 2003, the number of high school graduates in the program increased from 472,363 to 587,292 in 2008, and more than half of the participants were women. Undergraduate education increased from 835,596 to $2,006,348$ between 2000 and 2008. Graduate enrollment increased from 58,882 to 102,983 in the same period. However, Misión Sucre did not lead to a removal of barriers of entry to university education, which was why Chávez launched Misión Alma Mater. In this mission, Chávez transformed 29 public universities into national experiments. These universities were tied to the vocational, cultural, and social needs of their constituents. As a result of Misión Sucre and Misión Alma Mater, Venezuela increased university education enrollment, joining an elite club with Cuba, South Korea, Finland, Slovenia, and Greece. ${ }^{11}$

\section{ALBA and Socialism}

Joel Hirst and Christopher Sabatini find in their research that ALBA has three major goals. The first is to promote conflict, especially against the U.S. and its capitalist allies. According to many prominent leaders of the ALBA social movements, the conflict is to help Latin America and the Caribbean contest U.S. hegemony and imperialism. The second goal is to promote socialism. The last goal of ALBA is to promote a world revolution. In this revolution, ALBA would support other revolutionary groups, including Hezbollah, the Revolutionary Armed Forces of Colombia, the Colombian National Liberation Army, and Basque terrorist groups in Spain. Consequently, ALBA is interested in creating a multipolar international system that balances the U.S. and allow revolutionaries to guide politics. ${ }^{12}$

\footnotetext{
11 Thomas Muhr, Venezuela and the ALBA: Counter-Hegemony, Geographies of Integration and Development, and Higher Education for All (Saarbucken: Verlag Dr. Muller, 2011,) 148-52, 154-155.

12 Joel Hirst and Christopher Sabatini, "A Guide to ALBA: What is the Bolivarian Alternative to the Americas and What Does It Do?," in Decline of the United States Hegemony? A Challenge of ALBA and a New Latin American Integration of the Twenty-First Century, eds. Bruce Bagley and Magdalena Defort (Lanham: Lexington Books, 2015), 202-204.
} 
Josette Borbón suggests that as an organization that promotes multilateralism, the results of ALBA are varied. Many of the members joined ALBA due to their political leaders. Consequently, the leaders chose the initiatives that they wanted to promote. Additionally, ALBA is focused on government cooperation and not societal dialogue and collaboration. Some ALBA members resented that states such as Argentina and Paraguay did not join, especially because Néstor Kirchner, former president of Argentina, was a leftist. ${ }^{13}$

It is no surprise that many of the leaders of the ALBA members were sympathetic to socialism. The presidents of Venezuela, Bolivia, Ecuador, and Nicaragua had unparalleled support from their citizens. However, many scholars have noted that the 2010s was the decade of decline for socialism. In Ecuador, for example, former president Rafael Correa faced opposition in 2010 due to police violence and public riots that forced him to declare a state of emergency. In 2011, he was challenged by an indigenous rights activist group for the inhumane treatment of indigenous people in the Amazon. The same group sued Correa and brought him to the InterAmerican Commission on Human Rights. ${ }^{14}$ Former president of Bolivia, Evo Morales, faced domestic opposition in 2011 when he increased the price of food and transportation. As a result, protests were staged against Morales for neglecting the needs of the Bolivian citizens. ${ }^{15}$

One of the most interesting aspects of socialism in ALBA was Barrio Adentro. It was an exemplary project of socialism since the mission encompassed happiness and wellbeing in addition to patient health. The mission improved the medical services provided to clients, and the doctors were caring. Doctors were reported to embrace patients, express sympathy, and establish eye contact with patients. Furthermore, doctors made routine visits to the barrios and offered care

\footnotetext{
${ }^{13}$ Josette Altmann Borbón, “ALBA: Ideology Overcomes Integration?," in Decline of the United States Hegemony? A Challenge of ALBA and a New Latin American Integration of the Twenty-First Century, eds. Bruce Bagley and Magdalena Defort (Lanham: Lexington Books, 2015), 74-5.

${ }^{14}$ Borbón, “ALBA: Ideology Overcomes Integration?,” 88-99.

${ }^{15}$ Ibid., 89.
} 
to patients at home. All types of professionals, such as psychologists, dentists, and social workers visited patients. ${ }^{16}$ Barrio Adentro also included a Club de Abuelos, where the government employed sports and dance trainers to offer therapy sessions to the elderly to assist with medical issues, such as heart disease and high blood pressure. It was celebrated because it was fun. ${ }^{17}$

Barrio Adentro was important since it gave inclusion back to the excluidos (the excluded). In the Venezuela, the excluidos were the poor, indigenous, blacks, and women that were left behind in the pre-Chávez era. For decades, Venezuela did not have universal healthcare and the private healthcare was not an option for the most vulnerable sectors of the population. When Chávez implemented the Barrio Adentro program, the excluidos felt included in society. The excluidos believed that having access to health care would allow them to become part of discussions related to societal dilemmas. ${ }^{18}$ However, once Maduro became the president of Venezuela, problems began to emerge. Even though he supported Barrio Adentro, the government was not able to offer medical supplies to attend to all patients. Due to the fall of oil prices, domestic opposition to Maduro emerged and called into question his legitimacy. Furthermore, people who benefited from Barrio Adentro were scared that the program would disappear once a right-wing government came into power. Additionally, the domestic situation was falling apart because the country had food shortages, high malnutrition, infant and maternal mortality, spread of disease, and a worthless currency. Consequently, it appeared that the government abandoned the excluidos. Barrio Adentro clinics and hospitals were ransacked and medicine supplies were low. ${ }^{19}$ By 2017 , Venezuelans were not receiving the same level of free

\footnotetext{
${ }^{16}$ Amy Cooper, State of Health: Pleasure and Politics in Venezuelan Health Care under Chávez (Oakland: University of California Press, 2019): 9-11, 15.

${ }^{17}$ Cooper, State of Health, 2.

${ }^{18}$ Ibid., 40-41, 43.

${ }^{19}$ Ibid., 148-151.
} 
medical services as in 2008 but most were still happy with their empathetic doctors. Even though in the past decade Venezuela fell apart, people were still grateful that Barrio Adentro was functioning and, more importantly, that the excluidos were recognized by the government. ${ }^{20}$ I will now provide an assessment of some ALBA initiatives and critique their achievement of a socialist alternative to neoliberalism. This will include The People's Trade Agreement (TCP), Unified Regional Compensation System (SUCRE), and Petrocaribe.

The People's Trade Agreement (ALBA-TCP)

When ALBA was first formed in 2004, it also held the title of the People's Trade Agreement (TCP). In the TCP, ALBA would make sure that trade, investment, and commerce were a means to achieve sustainable development. TCP grand projects included providing healthcare and education to the citizens of member states. Most important, special treatment would be provided to states that might not have the resources to provide to the TCP. Integration and cooperation were also expanded to communications and transportation between the member states. Joel Hirst notes that the TCP has several problems. First, the TCP is not a free trade agreement. He suggests that it is an agenda between the members to actually support each other's political projects. Second, ALBA and the TCP are founded on social justice and socialism. The objective is to improve cooperation to help fight inequality. Therefore, ALBA member leaders are able to support each other politically, and can avoid various issues in capitalism, such as supply and demand. Many ALBA members avoid this by directing expenditures to social justice while neglecting the state budget. Fourth, the ALBA-TCP was also an extension of the CubaVenezuela alliance, and Chávez used the providing of social justice to enhance his influence. ${ }^{21}$ Asa Cusack, a well-known researcher on Latin American and Caribbean affairs, further adds that the failure of the TCP occurred in various steps. The first issue is that the TCP was a

\footnotetext{
${ }^{20}$ Ibid., 152, 157.

${ }^{21}$ Joel Hirst, The ALBA: Inside Venezuela's Bolivarian Alliance (Miami: InterAmerican Institute for Democracy, 2012), 83-7, 96-8.
} 
guideline for multilateral investment and trade. The TCP was complicated by the fact that its two largest members, Venezuela and Ecuador, wanted to diminish the power of the U.S. while also increasing the strength of Latin America. Why is Ecuador important for the TCP? The TCP was added to ALBA in 2006 to extend Cuba-Venezuela trade to Bolivia and venture beyond the exchange of doctors for oil. When Ecuador joined ALBA in 2009, then president Correa decided he wanted his own TCP with Venezuela, called the Trade Agreement for Development (ACD). However, the TCP-ACD project did not achieve its goals because the member states could not agree on basic guidelines of negotiation and regulation. For example, in 2010, Correa wanted to pursue a Cooperation Framework Agreement (AMC) to provide Ecuador with economic development within the guidelines of the TCP. The AMC was another rhetorical document, with acknowledgment to vague ideas such as securing cooperation, and improving trade and development. The AMC was rejected in the Ecuador legislature, which terminated the project. ${ }^{22}$ What allowed for multilateral trade and cooperation to not be realized in the TCP? The first issue is that the trade between the TCP members was low. Inter-member trade was $3 \%$ while NAFTA inter-member trade was $40 \%$ and the European Union inter-member trade was $62 \%$. In the TCP, most of the trade was between Ecuador and Venezuela. The second issue is that the TCP had members who were a part of other regional agreements. Venezuela, for example, was a part of the Andean Community, and wanted a unilateral trade agreement with Cuba. Giving preferential treatment to Cuba would mean that the treatment would have to be extended to the other members. The Anglophone Caribbean island members of ALBA, for example, were also members of CARICOM and thus faced a dilemma as to whether to prioritize ALBA or CARICOM. ${ }^{23}$ The third issue is that the members of the TCP were members of the World Trade

\footnotetext{
${ }^{22}$ Asa Cusack, Venezuela, ALBA, and the Limits of Postneoliberal Regionalism in Latin America and the Caribbean (Palgrave: London, 2019), 95, 97-99, 102-103.

${ }^{23}$ Cusack, Venezuela, ALBA, and the Limits of Postneoliberal Regionalism in Latin America and the Caribbean, 106-107.
} 
Organization (WTO). As an international organization, the WTO has several guidelines that help facilitate trade and investment. For the TCP, the WTO is problematic because WTO regulations supersede those of the TCP. More troubling is that the TCP does not have a credible legal structure. As one legal scholar has noted, it would be practically impossible if ALBA made a trade agreement with India, for example, because ALBA regulations are unclear. Most the terms of agreement in the TCP were rhetorical, and flexibility is vague. ${ }^{24}$ The final issue with the TCP is that it caused a division between Ecuador and Venezuela. In the Correa government, infighting began between the foreign ministry and the production ministry, with the foreign minister favoring closer ties to Venezuela and publicly denouncing neoliberalism. The production minister feared that dependence on Venezuela would harm Ecuador. Ultimately, Correa's plan to improve the ACD and the AMC fell apart since he could not bridge his divided government.. ${ }^{25}$

Maribel Aponte-García, in contrast to Hirst and Cusack, dwells on two issues that the TCP tried to focus on: energy and food. Aponte-García finds that in following socialism, the TCP sought to provide a decent living for the people and allow the economy to be inclusive to all agents. The most important of these goals was to provide a good life for the citizens. This became problematic because not all ALBA members were socialist. Many of the Caribbean island members, for example, are democratic and capitalist. ${ }^{26}$ In the TCP, another key concept that is important is sovereignty. For the TCP, sovereignty includes the ability of the state to nationalize various economic corporations, increase taxes, and enforce industrialization. ${ }^{27}$

\footnotetext{
${ }^{24}$ Ibid., 108-109.

${ }^{25}$ Ibid., 112-113.

${ }^{26}$ Maribel Aponte-García, "The new strategic regionalism in the ALBA-TCP: alternatives to the food and energy crises," in Counter-Globalization and Socialism in the 21 ${ }^{\text {st }}$ Century: The Bolivarian Alliance for the Peoples of Our America, ed. Thomas Muhr (London: Routledge, 2013), 121, 123.

${ }^{27}$ Aponte- García, "The new strategic regionalism in the ALBA-TCP," 126.
} 
The issue of energy was unique because each of the TCP members had their own energy policies. In Venezuela, Chávez increased his control over PDVSA, the state oil company, and used its revenue to fund his social programs. Chávez also used PDVSA revenue to push for economic integration with the other TCP members for trade, investment, and energy. Ecuador was different since Correa decided that $90 \%$ of oil profits would go to the government. In Bolivia, Morales allowed for the oil companies to keep almost $20 \%$ of the oil revenue. ${ }^{28}$

A similar scenario may also be applied to the food agenda initiated by the TCP. In the beginning there was a debate between food security and food sovereignty. Food security refers to the right of people to have access to nutritious food, and food sovereignty is the right of people to grow their own food and for the government to protect farmers and food prices. The TCP created its own alternative to food security and sovereignty in 2008 with the Summit on Food Sovereignty and Security, when in the Final Declaration, the members agreed on various measures. The TCP members agreed to expropriate land for agricultural production and initiate an agricultural fund. A joint commission would be created to lead projects in vegetables, meat, milk, and cereals. State enterprises would be formed to link together public and private companies to integrate into the social economy. Venezuela and Cuba, for instance, formed the state enterprise Pescalba to integrate their fishing industries into their state economies. ALBA formed ALBAAvícola, which incorporated private poultry farms where the state would buy poultry from the farmers and pay them for the processing of food. Venezuela and Cuba later started Programa Campo Adentro, where Cuban agronomists and engineers were sent to the Venezuelan countryside to help modernize agriculture. Cuba was compensated with oil. ${ }^{29}$

The food initiative also came with problems. First, Venezuela decided to make agreements with other countries, including Argentina, Brazil, China, Belarus, and Iran. During

\footnotetext{
${ }^{28}$ Ibid., 126-127.

${ }^{29}$ Ibid., 130-131.
} 
the first years in power, Chávez expropriated one-third of total private land assets and transferred them to peasant farmers. It was reported that 180,000 peasants received land from the government by 2006 . However, about 200 peasants were assassinated by private mercenaries hired by the previous landowners. Almost all of the previous landowners who assassinated the peasants were able to escape justice. In Venezuela, the government went a step further than the TCP and launched Misión Mercal in 2008 to give food access to impoverished people. Misión Mercal was extended to provide nutritional supplements and grocery store access. ${ }^{30}$

\section{Unified Regional Compensation System (SUCRE)}

The SUCRE project began in 2009, when Ecuador joined ALBA. Cuba, Venezuela, Bolivia, Ecuador, and Nicaragua adopted SUCRE but was declined by the Caribbean island members. The goal of the initiative was to provide full employment in the member states and stabilize commercial and trade balance through a shared currency, called sucre. Additionally, the sucre was a floating currency and allowed member state currencies to be flexible. ${ }^{31}$ However, the sucre was tied to the U.S. dollar as a central currency. This is made even more apparent given that the U.S. dollar is the currency that Ecuador uses for legal tender. Despite the intention of increasing trade between ALBA members, SUCRE was not able to increase export output for the members. In 2009, for example, Venezuela was still the largest exporter for oil and minerals, followed by Ecuador. When excluding minerals and oil, the percentage of exports among the ALBA members was more balanced, with Ecuador being the main exporter and followed by Cuba, due to the trade of internationalists for Venezuelan oil. ${ }^{32}$

\footnotetext{
${ }^{30}$ Ibid., 132-133.

${ }^{31}$ Antulio Rosales and Manuel Cerezal, "The SUCRE and the ALBA-TCP Monetary Union: Responses from the South to the Global Crisis," in Counter-Globalization and Socialism in the $21^{\text {st }}$ Century: The Bolivarian Alliance for the Peoples of Our America, ed. Thomas Muhr (London: Routledge, 2013), 142143.

${ }^{32}$ Ibid., 145-146.
} 
Rosales and Cerezal note that since Latin America is an export-driven region, little is given for domestic production. Furthermore, in Latin America, the less industrialized states produce goods for domestic consumption in the industrialized states. SUCRE tried to solve this issue by allowing for the member states to increase trade among each other. However, this did not materialize because the ALBA members failed to diversify their economies. To illustrate, the first SUCRE transaction was in 2010, when Venezuela exported rice to Cuba. In the second transaction, Bolivia exported soy oil to Venezuela. Members such as Bolivia and Nicaragua were not able to contribute much to ALBA because of their status as less industrialized countries. Yet, states such as Venezuela and Ecuador have an incentive to increase organizational trade but fail to achieve it because less industrialized members cannot compete. ${ }^{33}$

The SUCRE project also shows signs of failure. First, SUCRE and ALBA were not able to account for the social and environmental concerns that result from trade integration. For example, there has been much discussion about the continued destruction of the Amazon forest. Additionally, it is unlikely that SUCRE will expand beyond ALBA. Second, ALBA depended on the political capital and will of member state leaders. Consequently, SUCRE and organizational trade seems dependent on certain personalities, and not that the ALBA members want to increase trade. This leads to the third issue that SUCRE and ALBA have, the lack of increasing institutional transformation with changing of leadership. As a result, if SUCRE and ALBA are projects to help decrease social and economic dilemmas, then, the policies and actions should stand on their own. ${ }^{34}$ Ultimately, what troubles ALBA is that it is attached to specific leaders, many of whom did not leave behind strong accountability and institutions.

Cusack finds some similar results with SUCRE. He argues that SUCRE had two major goals: one, to reduce foreign exchange, and two, to reduce costs of transaction. SUCRE is

\footnotetext{
${ }^{33}$ Ibid., 147, 149.

${ }^{34}$ Ibid., 150-151.
} 
different from the TCP because the use of the sucre currency helps members to recover from deficits. Since the largest transactions use sucre, the members who import more than they export can use the currency to lower the burden of deficit repayments. ${ }^{35}$ Cusack notes several issues that prevent SUCRE from being successful. First, the Anglophone Caribbean island members had their own currency and were lacking resources to contribute to inter-ALBA trade. Second, SURCE trade seemed to occur solely between Venezuela and Ecuador, which accounted for $98 \%$ of the project's trade transactions. Cusack is alarmed by this, noting that SUCRE's success appears to be tied to the wellbeing of Venezuela and its bilateral relationship with Ecuador. Third, almost all of the SUCRE trade has involved Ecuador exporting manufacturing products, such as machinery, to Venezuela in exchange for professionals involved in Barrio Adentro and Misión Mercal. The fourth issue is that the Venezuela and Ecuador bilateral trade is imbalanced because Venezuela depended on the high price of oil to pay for imports. Once the price of oil decreased, and the domestic situation worsened, Venezuela could offer little economic value to Ecuador. Fifth, not all members were supportive of using the sucre. For example, Ecuador tried to purchase medicine from Cuba using sucres, and Cuba wanted the payment to be in U.S. dollars. The last major issue was that Chávez had discussions of expanding SUCRE beyond ALBA. This involved rewriting the SUCRE treaty and member legislatures would have to re-ratify the treaty. Yet, when Chávez passed away in 2013, so did the idea of expansion. ${ }^{36}$

\section{Petrocaribe}

The last of the ALBA projects that will be discussed is Petrocaribe, an ambitious initiative. Petrocaribe involves 19 members, most of whom are also members of ALBA. In the initiative, the Anglophone Caribbean islands participate, but Cuba and Ecuador are absent. The reason for the absence of Cuba is that the island had a previous agreement in 2000 with

\footnotetext{
${ }^{35}$ Cosack, Venezuela, ALBA, and the Limits of Postneoliberal Regionalism in Latin America and the Caribbean, 119-121.

${ }^{36}$ Ibid., 129-130, 134-135, 141, 147.
} 
Venezuela to receive subsidized oil. Cuba is nominally a member of Petrocaribe, and the project has allowed for the Anglophone islands to get closer with Latin America. Venezuela, however, is at the center of Petrocaribe because the country was able to lend oil to the member states. ${ }^{37}$ As an oil-producing state, Venezuela was able to loan oil to Petrocaribe members and offer soft financing as well. In the loans, Venezuela offered low interest rates, and obtained investment as compensation. Ultimately, the soft financing was meant for state leaders to attend to social needs, which was derived from the Venezuelan Bank of Economic and Social Development. ${ }^{38}$

How does the sending of soft financing work? Depending on the Petrocaribe member, government leaders might be allowed to send raw materials, such as bananas, sugar, and other resources to Venezuela, and would be accepted as payment for oil. For Venezuela, Petrocaribe is beneficial because the project allows for the government to export its oil to various countries in Latin America and the Caribbean, which helps to undermine U.S. economic power. More important, by lending to Petrocaribe members, Venezuela attempted to help the member states to provide social welfare to the poor and minority populations. ${ }^{39}$

\section{A Constructivist Approach to the Socialist Alternative}

Eduardo Chacón notes that the socialism practiced by ALBA had seven key factors. First, socialism is a reaction to capitalism and its problems, including unemployment, increased debt, and impoverishment. In ALBA, beginning with Chávez, the leaders of Venezuela perceived themselves to be socialist leaders, and believed that they had a duty to spread socialism to neighboring countries. Additionally, Venezuela's leaders felt an inherent desire to assist blacks, small farmers, and the urban working class. Second, the Venezuelan government believed the Bolivarian Constitution to be a new symbol of freedom and hope in the country. For example,

\footnotetext{
${ }^{37}$ Ibid., 154-155.

${ }^{38}$ Ibid., 156, 158.

${ }^{39}$ Ibid., 159, 161.
} 
when a coup against the Bolivarian government failed in 2002, the socialist supporters staged protests and chanted in support of the Bolivarian constitution. ${ }^{40}$ Third, socialism encouraged citizens to become more empathetic toward societal problems. ALBA, therefore, considered that comprehensive humanitarian cooperation across health, sports, food, and social interaction would benefit the marginalized groups in societies of member states. Fourth, ALBA worked towards developing an ambitious educational social mission to provide literacy and educational opportunities. Cuba and Venezuela, through Yo Sí Puedo and Misión Robinson, were able to help illiterates in the member states become literate. Misión Robinson was the most ambitious, with five phases that included teaching indigenous people in their native languages. The mission was even paired with Misión Milagro and people were given eye treatment in addition to literacy instruction. ${ }^{41}$ Fifth, one of the main objectives of the humanitarian missions was to focus on providing emotional support and sympathy toward the clients. Sixth, ALBA desired to provide the marginalized groups of society with access to higher education. Furthermore, humanitarian missions were tasked with establishing venues for educational opportunities in the barrios. ${ }^{42}$ Finally, the ALBA leadership sought to instill the belief that the marginalized people are the vanguards of the revolution toward socialism. The leadership wanted the people to know that ALBA is continuing the struggle for the independence of the people left behind by capitalism. ${ }^{43}$

One of the central issues in this debate is the battle between ideas and material reality. Wendt perceives that in international relations, many theorists believe that issues between states may be reduced to material differences in power and security. He suggests that while there is

\footnotetext{
${ }^{40}$ Eduardo Chacón, "Twenty-First Century Socialism: A Political and Pedagogical Act: Some Keys to Understand," In Counter-Globalization and Socialism in the $21^{\text {st }}$ Century, ed. Thomas Muhr (New York: Routledge, 2013), 33-35.

${ }^{41}$ Chacón, "Twenty-First Century Socialism," 35-38.

${ }^{42}$ Ibid., 39-40.

${ }^{43}$ Ibid., 43.
} 
inequality in the world, ideas help form our material reality. For Wendt, the difference between capitalism and socialism is the mode of production, with socialism focusing on the relationship of workers and their production tools. ${ }^{44}$ Material reality, for him, has three major effects in international relations. First, the distribution of material resources affects some outcomes. States have resources, and when leaders use those resources, then certain political outcomes are likely to occur. Second, the material capabilities and technological capacity impact the ideas that actors conjure. For example, once certain technology is created, it influences how actors conceive new technology. Third, geography and natural resources influence the decisions made by state leaders. These material factors are made more impactful because actors heavily interact with these material forces to make political, economic, and cultural decisions. ${ }^{45}$

How much can people change their material reality? People can change the political leadership and the guiding ideology and philosophy. People can also change natural resources and geographic limitations. However, people cannot infinitely change geography, and second, people cannot always change the distribution of power. ${ }^{46}$ The question then becomes Did ALBA achieve its goal of providing a socialist alternative to neoliberalism? To answer this question, I will discuss some of the different ALBA members, starting with Cuba. For Cuba, ALBA was not a successful socialist alternative to U.S. economic hegemony. Cuba has been plagued by the U.S. economic embargo, which limits access to foreign trade and prevents the use of the U.S. dollar in international trade. In a speech in 2009 , Correa noted that Cuba was still infected with poverty and that ALBA was an extension of the good parts of socialism. The TCP, for example, was concerned with decreasing the influence of private industry in the economy. This, however, did not concern Cuba because it is socialist. What Cuba desired was to avoid more economic damage

\footnotetext{
${ }^{44}$ Wendt, Social Theory of International Politics, 94-95.

${ }^{45}$ Ibid., 110-112.

${ }^{46}$ Ibid., 112-113.
} 
caused by the U.S. embargo, and it decided to have bilateral agreements with the different members instead. Yet, Cuba only made agreements with Venezuela, Bolivia, Nicaragua, Dominica, and Saint Vincent and the Grenadines. Moreover, in these bilateral agreements, Cuba established, by 2009, 100 educational, sports, health, tourist, and transportation programs in the different countries. However, Cuba considers the Caribbean ALBA members (Dominica, Saint Vincent and the Grenadines, and Antigua and Barbuda) as not significant for international economic trade due to their material conditions. The islands have in total about 260,000 people and 1,000 square millage and cannot produce much material goods. ${ }^{47}$

As the evidence suggests, Cuba believes that its economy may stay afloat if it pursues bilateral agreements with the different members of ALBA. While socialism is the guiding ideology of ALBA, different state leaders see that Cuba still has material problems. This is exactly what Wendt discussed. It does not matter if Cuba and ALBA are socialist because Cuba is an island with limited resources and the U.S. embargo has forced Cuba to look to Central and South America and the Caribbean for economic assistance. Furthermore, it appears that Cuba is widely respected in the region for defying the U.S. since 1959, but socialism as an economic and political model might not be the best strategy for other ALBA members. Therefore, the material reality has prevented ALBA from becoming a socialist alternative. The members enjoy that Cuba has been able to supply thousands of health professionals over the decades. They also enjoy that many of the professionals have a strong conviction to the Revolution and socialism. Yet, none of the ALBA members can escape that Cuba is still impoverished. Consequently, Cuban socialism has not been replicated, but its leaders are often respected for their attempt to defy neoliberalism.

One of the leading reasons why ALBA failed to achieve a socialist alternative to the U.S. hegemonic economic system is that the different ALBA programs are connected to Venezuela. For example, in the TCP, members such as Bolivia and Ecuador desired stronger institutions that

\footnotetext{
${ }^{47}$ Helen Yaffe, "Cuban Socialism: inspiration to the ALBA-TCP," in Counter-Globalization and Socialism in the $21^{s t}$ Century, ed. Thomas Muhr (New York: Routledge, 2013), 101, 105, 114-115.
} 
would create binding trade agreements and work within the existing international economic order. Venezuela, in contrast, had a special trade relationship with Cuba, and was not willing to expand preferential treatment to the other members. Furthermore, Ecuador was an important trading partner for Venezuela in the TCP. ${ }^{48}$ The ALBA members were also part of the WTO, and the members did not to divorce completely from the international economy. In practice, if ALBA members tried to circumvent the WTO, they would place their economies at risk. ${ }^{49}$ Similarly, SUCRE created some dilemmas for ALBA members. Like the TCP, Ecuador was a grand beneficiary, with a more diverse economic output that competed with Venezuela's importdependent political economy. Additionally, the sucre currency was not practical because Ecuador used the U.S. dollar as its legal tender. Ecuador also favored comprehensive trade free of regulation. Venezuela, however, disagreed and used its hegemonic position to compel Ecuador to accept payments in sucres. Despite, Venezuela could not accept that Ecuador was becoming more economically competitive. For example, Ecuador produced automobiles, milk, and other raw and mechanical materials comparatively better than Venezuela. ${ }^{50}$

Petrocaribe also shows many problematic traits. First, much of Petrocaribe was managed by the Energy Ministry in Venezuela, and such institutional power resided in the country. As a result, Venezuela remained as the decider of which countries received oil. More important, it kept competitors such as Bolivia and Ecuador from contesting power. Furthermore, Petrocaribe is politically dangerous not only because Venezuela is the link between the project and ALBA member states, but Petrocaribe depends on the socialist party maintaining power in Venezuela. ${ }^{51}$

\footnotetext{
${ }^{48}$ Cosack, Venezuela, ALBA, and the Limits of Postneoliberal Regionalism in Latin America and the Caribbean, 106-8.

${ }^{49}$ Ibid., 108-109.

${ }^{50}$ Ibid., 120, 142, 144-145.

${ }^{51}$ Ibid., 181-182.
} 
The desire to create a socialist alternative also failed because Venezuela treated ALBA as a brand. It was practically impossible for Chávez to provide institutional oversight for ALBA and maintain political power in Venezuela and influence abroad. One of these had to be given up, and he chose to neglect institutional design for ALBA. Chávez, for instance, did not provide intensive oversight in the oil industry, and there appeared to be little accountability for officials when unfavorable events occurred. This worsened when Maduro assumed power. He increased socialist rhetoric, and meaningful connections with all ALBA members, expect Cuba, disappeared. Maduro has become extremely inflexible, even though Venezuela has a medicine and food shortage, and democracy has practically become nonexistent. ${ }^{52}$ While Venezuela tried to become a socialist leader with its emphasis on humanitarian assistance for the poor people, increasing government power, and maintaining the primacy of oil in the economy, none of these factors were guaranteed to succeed. On the contrary, Venezuela faced ideological opposition from other state members who kept capitalism. Ecuador, for instance, maintained capitalism and increased taxes to bring revenue for the government and to protect social welfare. Most important, the Ecuadorian government did not expropriate private property, unlike Venezuela, which prevented conflict with the elites. Actions such as these helped Ecuador to diminish its role in ALBA before Correa's term ended in $2017 .{ }^{53}$ Many of the ALBA members were capitalist and their economic system was not going to disappear in the near future. Quite the opposite, countries such as Bolivia and Ecuador showed that the governments could attend to the needs of the marginalized groups of society without turning to socialism. This kept the economic elite in the country and helped to decrease international condemnation over the regime. ${ }^{54}$

\footnotetext{
52 Ibid., 193-194.

${ }^{53}$ Ibid., 196-198.

${ }^{54}$ Ibid., 199.
} 


\section{Conclusion}

ALBA did not create a socialist alternative to neoliberalism. This is explained through the multiple ALBA initiatives: TCP, SUCRE, Petrocaribe. From the start, the TCP was not a successful initiative for socialism for several reasons. First, many members had bilateral trade agreements, and many were not willing to extend preferential treatment to the TCP and the rest of ALBA. The second issue with the TCP is that many of the members did not have enough natural resources or industrial capacity and human capital to become economically competitive. for members who desired bilateral agreements instead of multilateral cooperation. The third issue with the TCP is that all ALBA members are also part of the WTO and subject to its regulations.

A socialist alternative cannot be created since the socialist organization exists in a capitalist trade system which promotes capitalism. This is especially true since not all ALBA members are socialist or subscribe to socialism as a political and economic system. Therefore, ALBA remains a bastion of rhetoric because it has not found a way to spread socialism across all members nor to create a socialist organization that could challenge neoliberalism.

SUCRE was the other ALBA initiative discussed. Two major dilemmas prevented SUCRE from assisting ALBA with the creation of a socialist alternative. First, the ALBA members failed to diversify their economies. The second issue with SUCRE is that the sucre currency was not accepted by all members and was not consistently used.

A third ALBA initiative that was given attention was Petrocaribe. Petrocaribe benefited from the fact that Venezuela had large supplies of oil to lend to various countries in exchange for political and economic support. As the leader of Petrocaribe, Venezuela was able to establish some ground rules that were believed to benefit the country. However, while Venezuela had intentions of spreading socialism, only a few countries decided to follow suit in political support. This is the problem with Petrocaribe and ALBA. Both organizations are dependent on Venezuela, and the international economic system allowed for Venezuela to benefit for a while. But once the 
international economic system was no longer benefiting the political and economic needs of Venezuela, the international support for ALBA and Petrocaribe fell through.

Wendt offered the best constructivist approach to what occurred. He seems to be correct in asserting that actors in international relations can change their material reality, but not everything can be changed. In the case of ALBA, Venezuela and Cuba tried to change their reality by creating a socialist organization that could challenge the United States. This ultimately failed because the leading member of the organization, Venezuela, is not socialist and played in the capitalist system to improve its citizens' welfare. Wendt explains clearly when he argues that words are simply words unless there are actors who can change rhetoric into action. In Venezuela, Chávez was the leading actor who created action, but his action did not match what socialism entails. This is where the analysis provided by Wendt is effective, since he insinuates that people are ultimately limited by their material reality. We can also couple this with the analysis provided by Onuf, especially since rules are made to benefit certain people. In ALBA, Venezuela benefited because Chávez had a special relationship with Fidel. Not only that, Chávez had rhetorical skill and a likeable personality among the people to win their political support. Therefore, when ALBA was, he wanted Venezuela to be dominant in the relationship.

ALBA, consequently, was not truly may be viewed as failing to create a socialist alternative to neoliberalism since Venezuela socialist and did not fully provide for the needs of its people. It cannot be stressed enough that ALBA worked when Chávez and Fidel were alive, but once new leadership arrived, ALBA fell apart. Maduro could not sustain Barrio Adentro and many members did not use the sucre currency and many more wanted bilateral TCP agreements and not a multilateral agreement. These factors revolved around the socialist rhetoric, the capitalist nature of its members, and the sustainability of the humanitarian missions, which did not match up. Additionally, the material reality did not match the socialist rhetoric and that is why ALBA failed to create a socialist alternative to neoliberalism. 


\section{CHAPTER IV DIVERGENCE}

In this chapter, I will discuss the impact of the leadership change on the exit of three former members of ALBA. Additionally, I will also highlight how ALBA was unable to foster cooperation. Special attention will be given to Venezuela's decision to welcome to extraregional actors on a bilateral basis. I will show that many ALBA members were left behind because they could not offer many of the same goods and services as Venezuela.

The First State to Leave

In 2008, then president of Honduras, Manuel Zelaya decided to join ALBA. The most important reason why Zelaya decided to join ALBA was that Honduras was facing an economic crisis in 2008 and joining ALBA was a way to escape economic hardship. ${ }^{1}$ However, division emerged in the country when Zelaya suggested that a constituent assembly should be created, in the style of Venezuela. In the assembly, the people would be empowered and given vast amounts of authority over the congress. Naturally this did not bode well with the legislators, and the country divided in two camps. ${ }^{2}$ Initially, some members of the military supported Zelaya, but once Zelaya removed General Romero Velásquez as head of the armed forces, the military became antagonistic toward the president. The Supreme Court ruled that Zelaya had to be removed from office, but General Velasquez instead sent him to Costa Rica for exile. ${ }^{3}$ New elections were held later in 2009 and Porfirio Lobos won. The new administration left ALBA.

During this time, Honduras had a powerful two-party system that was deeply embedded in the hands of powerful oligarchic families. Additionally, the differences between the National Party and the Liberal Party were the candidates' personalities. Neoliberalism divided the country because some political actors wanted more government engagement to help the poor and others

\footnotetext{
${ }^{1}$ Carlos de la Torre, "A Populist International? ALBA's Democratic and Autocratic Promotion," SAIS Review of International Affairs 37, no. 1 (Winter-Spring 2017): 85.

${ }^{2}$ de la Torre, “A Populist International?,” 86.

${ }^{3}$ Ibid., 86.
} 
wanted less government involvement. ${ }^{4}$ Once Zelaya was removed, many of the government institutions remained, and various sectors of society had supported his removal, including the middle class and the church. Therefore, it is little surprise that Zelaya was forced into exile, particularly because he involved the military in civilian issues. The political establishment feared their loss of privileges if Honduras ventured the same path as Venezuela. ${ }^{5}$

The Honduras exit is best explained by the problem of rules and order. For Onuf, orders and decrees are made legal when their rules are consented. Rules are organized by international regimes. As a result, rules are related to privilege, and whomever creates and enforces the rules has privilege. ${ }^{6}$ Rules become complex when leaders make self-declared declarations. These are rules conceived on special occasions and are difficult to place within a legal order. ${ }^{7}$

From the constructivist view, the Honduras exit from ALBA is partly attributed to the fact that Zelaya wanted to change the rules of his state and ally with Venezuela. However, many members of congress and his cabinet disagreed, and a coup was considered to prevent the state from joining ALBA. ${ }^{8}$ Zelaya desired to implement a popular sovereignty model that would grant more power to the people. ${ }^{9}$ Government officials removed Zelaya to keep the status quo.

The battle in Honduras was whether to maintain the rules-based system that existed or to create a new one based on Venezuela's social and political system. It was risky because new values and institutional changes would have to be accommodated. Most important, many of the government officials benefited from working in the existing political system. Therefore, it was considered dangerous to change the system and follow the path of Venezuela.

\footnotetext{
${ }^{4}$ Ibid, 86.

${ }^{5}$ Ibid, 87.

${ }^{6}$ Onuf, World of Our Making, 127-128.

${ }^{7}$ Ibid., 137.

${ }^{8}$ de la Torre, “A Populist International?,” 86.

${ }^{9}$ Ibid., 86.
} 


\section{Ecuador Leaves ALBA}

From 2007-17, Rafael Correa was the president of Ecuador, and he led the country's admission to ALBA, where he joined a whole cast of leftist leaders who were sympathetic toward socialism. During the later years of his administration, he chose a new vice president, Lenín Moreno, who conflicted with him on various issues. As writer Rafael Rojas, in the Havana Times, argues, Cuba considered Moreno a threat since he did not share the same convictions toward socialism. Moreno was interested in allying Ecuador with the global capitalist system and allowing for international credit to enter the country. Moreno was also vocal about developing greater transparency in Ecuador. This harmed Correa since Moreno wanted an investigation concerning why the Odebrecht conglomerate could do business in Ecuador. Suspicions concerning corruption were circulating, and Moreno desired answers. ${ }^{10}$ Clearly, Moreno was not liked in the Correa cabinet, many of whom benefited from the Odebrecht connection.

Throughout the Correa regime, various moments coalesced to help the country exit from ALBA. The first was that Correa was not interested in displacing neoliberalism with socialism. Instead, he wanted to reform neoliberalism to allow it to lessen social inequality. He worked to expand social security membership and to increase the collection of taxes for all government agencies. ${ }^{11}$ Second, Correa received less international condemnation compared to Venezuela. Additionally, his administration had less infighting, so Correa could spend more time improving the domestic situation for Ecuador. Third, around 2014, Ecuadorean exports suffered since the U.S. dollar had appreciated in value. ${ }^{12}$ This was a major factor that prevented Ecuador from

\footnotetext{
${ }^{10}$ Rafael Rojas, "Ecuador: Lenin Moreno, the Troubling Successor to Rafael Correa," Havana Times, accessed August 2, 2020, https://havanatimes.org/news/ecuador-lenin-moreno-the-troubling-successor-torafael-correa/.

${ }^{11}$ Cosack, Venezuela, ALBA, and the Limits of Postneoliberal Regionalism in Latin America and the Caribbean, 198.

${ }^{12}$ Ibid., 198.
} 
becoming more involved in ALBA. Since many of the ALBA initiatives were concerned with creating a new economic space, Ecuador could not afford to divorce from neoliberalism.

In 1979, Ecuador experienced a transition from a military dictatorship to democracy. However, the decades following were turbulent. Correa gained national recognition as economic minister for interim president Alfredo Palacio from 2005-2007. Correa was anti-neoliberal and held national appeal as a result of his $\mathrm{PhD}$ education and declaring himself to be a savior for the country from the neoliberal elite. As a populist, he greatly expanded executive power to restrict basic freedoms and expand presidential term restrictions. ${ }^{13}$ Correa behaved as a populist by increasing government control of the media and restructuring the judiciary. ${ }^{14}$

From a constructivist perspective, what assisted the exit of Ecuador was that the country was an economic competitor to Venezuela. Throughout its membership in ALBA, the two states had competed to decide which had the better humanitarian system or which had the greatest gains in exports. As a result, Correa was focusing on the material reality, which was that Ecuador was a midlevel economic actor in South America and could rise to become a greater power with an encouraging leadership. Partly as a result, Correa decided it was best to focus on domestic developments. Moreover, it was suspected that Ecuador was going to stay while Correa was in power. When Moreno was elected, he perceived that new alliances were in his best interests. The Ecuador exit may be best explained through Wendt's analysis of materialism and culture. For him, materialism and culture are important because they are formulated by ideas and their relationship to material goods. ${ }^{15}$ Ideas such as capitalism become important since actors

\footnotetext{
${ }^{13}$ Selcuk, Orcun, "Strong presidents and weak institutions: populism in Turkey, Venezuela, and Ecuador," Southeast European and Black Sea Studies 16, no. 4 (September 2016): 581.

${ }^{14}$ Selcuk, "Strong presidents and weak institutions," 582.

${ }^{15}$ Wendt, Social Theory of International Politics, 94-95.
} 
relate it to societal institutions, power, and material interests. ${ }^{16}$ Wendt shows the role of ideas by looking at Marxism, an ideology that critiques the impact of material goods and production in society. He shows that the material factor discussed in Marxism is capitalism, which is an idea that has been created in society. Capitalism exists because human culture has created it and developed it throughout the centuries. It exists because of human interaction. ${ }^{17}$

ALBA had various issues which conflicted with the interests of Correa. First, Correa was an intellectual with a doctorate degree from the University of Illinois. Chávez, on the other hand, only had a military background, while Evo Morales had little formal education. ${ }^{18}$ Based on education alone, Correa worked with leaders who were not the better educated of their countries.

Second, Correa developed strong bilateral relations with Cuba. As a result of the relationship, Cuba offered projects in health, energy, tourism, and education. In 2012, Ecuador was an active participant and the 13,000 Cuban and 18,000 Venezuelan personnel were applauded for guiding Correa in the ALBA projects. ${ }^{19}$ Lastly, Correa gained power while reworking Ecuador's domestic politics. He rewrote the constitution to let him stay in power until 2017 and he packed the court system with his supporters. Furthermore, he worked to restrict private property and freedom of speech. These actions allowed him to amass power. ${ }^{20}$

The exit of Ecuador from ALBA is of little surprise. To begin, Correa was an intellectual and he desired to consolidate his power first before venturing to ALBA. He was concerned with the ideational reality that opposition existed, and he needed to manipulate the domestic political system to remove that threat. From a constructivist view, this makes sense because Correa wanted

\footnotetext{
${ }^{16}$ Ibid., 95.

${ }^{17}$ Ibid., 95.

${ }^{18}$ Hirst, The ALBA, 206.

${ }^{19}$ Ibid., 205.

${ }^{20}$ Ibid., 203-205.
} 
to change the political culture to his liking. Correa was able to change the political system by curtailing certain freedoms and packing the government with supporters. As a result, amassing power was ideational because he brought like-minded people into authority.

The other issue was that Correa kept the U.S. dollar as the official currency of the country. This was done to keep the economy stable, but it also tied Ecuador to neoliberalism. Therefore, Ecuador could not fully participate in the ALBA programs, since the state was tied to the U.S. economy. Ecuador depended less on ALBA for human and material resources, unlike some of the other members, especially Nicaragua and Bolivia. Essentially, Ecuador was not bound to stay in ALBA. Correa and Moreno decided it was better to focus on domestic politics.

Bolivia Leaves the Bolivarian Alliance

In 2006, Evo Morales was elected as the president of Bolivia, where he ruled until national protests forced him out of power in 2019. During his presidency, he led the development of a new constitution that recognized indigenous people and gave the government more economic power. ${ }^{21}$ Furthermore, he led increased government spending in education, infrastructure, and health. Morales tacked poverty by initiating pension grant programs that helped better the quality of life for women, children, the elderly, and other vulnerable groups. Consequently, from 2006 until 2014, Morales helped to equalize the different societal groups. ${ }^{22}$

Even though Morales helped to decrease rates of poverty, school dropouts, and maternal mortality, the country was still dependent on gas and oil as the main source of export revenue. However, Morales was unable to stimulate the economy. One reason was that private investment was severely lacking. Private industry lacked meaningful regulation, which was often sporadic.

\footnotetext{
${ }^{21}$ Juan Pablo Bohoslavsky, "Development and Human Rights in Bolivia: Advances, Contradictions, and Challenges," Latin American Policy 11, no.1 (2020): 128.

${ }^{22}$ Bohoslavsky, "Development and Human Rights in Bolivia," 129.
} 
Additionally, private industry considered the state's tax system to be too strict. ${ }^{23}$ Another reason was that labor regulations were considered burdensome. Many private corporations complained that individual and collective labor rights were not efficient for capitalism. The government was also intrusive in private industry, and the business environment was not friendly. ${ }^{24}$

A third factor that prevented sustained economic growth has been a lack of research and development. Many of the First World states have digitized their services, which leaves Third World states behind. Bolivia is one among many countries with a deficit in innovation, technology, and productivity. ${ }^{25}$ Lastly, Bolivia has used a fixed exchange rate to increase spending and control inflation, which has led to an overvalued currency. ${ }^{26}$

Under Morales, the Bolivian economy was plagued by issues that prevented economic growth. As a result, while Morales claimed to have improved the human rights situation of ordinary Bolivians, the material reality was that the economy was not growing. Therefore, from a constructivist view, Morales acted as an influential. He was concerned about the struggles of vulnerable groups of society. As the president, he could decide which groups needed economic support. However, Morales did not provide incentives for private investment in Bolivia, which resulted in less economic growth and development. This affected funds for his welfare policies.

In 2013, the Movimento al Socialismo Party (MAS) had succeeded in getting Morales a third term. However, from 2014-19, the international price of natural resources such as oil and gas dropped, and the Morales government could not recuperate the cost. Furthermore, Morales had an approval rating that was below 50\%, and supporters feared an electoral loss in $2019 .{ }^{27}$

\footnotetext{
${ }^{23}$ Ibid., 130-131.

${ }^{24}$ Ibid., 131.

${ }^{25}$ Ibid., 132.

${ }^{26}$ Ibid., 132.

${ }^{27}$ Fabrice Lehocuq, “Bolivia’s Citizen Revolt,” Journal of Democracy 31, no. 3 (July 2020): 132-133.
} 
In the 2019 election, the Organization of American States (OAS) suspected voter fraud and demanded a recount. The OAS found irregularities and significant manipulation of votes that compromised electoral integrity. Within 48 hours of the election, people went to the streets to demonstrate, where election offices were attacked. Morales then decided to leave for Mexico. ${ }^{28}$ His replacement was the Vice-President of the Senate, Jeanine Áñez, who decided to have Bolivia leave ALBA. She appointed new ambassadors to replace those from Morales. ${ }^{29}$

Morales had used ideas of socialism and protecting of vulnerable people to win office. As Wendt argues, ideas become important with a material context considered along with it. Interests, power, institutions, and material reality are interdependent. Moreover, power and interest become important because people attach ideas and significance to them. Yet, one must not forget that material reality has an essential role in balancing ideas. ${ }^{30}$ When considering the Morales exit, it is important to realize that the social programs he implemented worked when the country received extensive revenue from gas and oil. However, he used his socialist ideas did not lead to growth.

For decades Bolivia had massive political instability. Between 1958 and 2007, Bolivia witnessed the growth of large political organizations and movements. President Sánchez de Lozada had to resign in 2003 as a result of the Black October incident. His successor was Carlos Mesa, who presided over the country for twenty months and then resigned because of political instability. Such uncertainty came to close in 2005, when Evo Morales was elected. Under Morales, MAS became the hegemonic party in Bolivia and helped to lead reforms across the executive, legislator, and judiciary branches. Electoral reform was also conducted under MAS. ${ }^{31}$

\footnotetext{
${ }^{28}$ Lehocuq, "Bolivia’s Citizen Revolt,” 134-136.

29 "Bolivia withdraws from ALBA, recalls most of its ambassadors," Xinhua, accessed August 5, 2020, http://www.xinhuanet.com/english/2019-11/16/c 138559166.htm.

${ }^{30}$ Wendt, Social Theory of International Politics, 94-96.

${ }^{31}$ Betilde Muñoz-Pogossian, Electoral Rules and The Transformation of Bolivian Politics: The Rise of Evo Morales (New York: Palgrave Macmillan, 2008), 1-2.
} 
Since the Morales government could not recover from the bad publicity created by the election and investigation, he had to resign. From a constructivist view, this is important because the idea of an election was compromised by the actions that Morales took in his presidency. The idea of a just government was wiped away because Morales held power longer than he was supposed to. Even if the constitution was changed, it still does not negate that Morales became corrupt by power. Therefore, Bolivians decided that a new leadership was needed.

The material reality of Bolivia changed when interim president Áñez decided that Bolivia would take a conservative turn in politics. Since conservatism is inherently different from socialism, Bolivia would have to divorce from the many leftist governments in the region. This was accomplished by breaking away from ALBA. Consequently, Áñez changed the ideas and material reality of Bolivia, especially since the new government would be critical of socialism.

\section{Iran: A Selective Relationship with ALBA}

The first extraregional actor that will be discussed is Iran. This is a unique relationship because Iran has observer status in ALBA. Since 2007-08, trade between ALBA and Iran has grown. On several state visits, Iranian leaders have proclaimed joint agreements where they will fund the development of hospitals, aid funds, ports, and lithium and uranium mines. What was most striking was how quickly the ALBA leadership would listen and adhere to the demands of Iran. For example, in 2007 Iran made an official visit to Bolivia where Iran agreed to provide development funds to Bolivia. In the same visit, Bolivia decided to move its one embassy in the Middle East to Tehran, Iran and officially broke ties with Israel. ${ }^{32}$

Iran is a special case since it too experienced a revolution that brought a new regime. As a result of the 1979 revolution, Iran became an Islamic Republic. ${ }^{33}$ More important, its

\footnotetext{
${ }^{32}$ Hirst, The ALBA, 211-214.

${ }^{33}$ Humire, Joseph, “Preface Iran's Intrusion: An Overview," in Iran's Strategic Penetration of Latin America, eds. Joseph Humire and Ilan Berman (Lanham: Lexington Books, 2014), xv.
} 
involvement in Latin America and the Caribbean began shortly after the revolution, where Iran supported Hezbollah terrorist activity in the region. Iran took responsibility for the 1994 Buenos Aires terrorist attack against the Israel embassy. Iran also supported al-Qaeda and Hamas in the region. Yet, the region became important to Iran after the inauguration of Hugo Chávez as president of Venezuela in 1999. Chávez protected the finances of Hezbollah and training of the Revolutionary Armed Guards in Venezuela. ${ }^{34}$ More important, Venezuela became the gateway to the Americas and allowed Iran to develop strategic, political, and economic relationships with countries in the region, such as Bolivia. Consequently, Iran's diplomatic recognition in the region encompassed eleven embassies in 2014 as opposed to five in $2005 .^{35}$

The ties between Iran and Venezuela are more concerning for the region. In 2010, Venezuela agreed that people from Iran would no longer need visas to travel to the country. Additionally, cargo would not have to go through customs. An unintended consequence of this decision has been that Venezuela was able to support terrorism originating from Iran and to support regional terrorism. In Bolivia, Iran owns and operates a television station that broadcasts Shiite Muslim programs. Furthermore, Iran forced nurses in Bolivian hospitals to wear hijabs, even if they were not Muslim. In Venezuela, Iran owns the Venezuelan development bank, and its entire board is filled by Iranians. ${ }^{36}$ Iran, as a consequence, can determine major economic decisions in Venezuela with little accountability or Bolivarian government oversight.

The Iran-ALBA relationship is not based on religion or even economics, but rather on ideology. However, the ideology of Iran is not inspired by socialism. The goal of Iran is to create a multipolar international system where the U.S. is not the hegemon. A foundation of the Iranian

\footnotetext{
${ }^{34}$ Berman, Ilan, "What Iran wants in the Americas," in Iran's Strategic Penetration of Latin America, eds. Joseph Humire and Ilan Berman (Lanham: Lexington Books, 2014), 2.

${ }^{35}$ Berman, Ilan, "What Iran wants in the Americas," 3.

${ }^{36}$ Hirst, The ALBA, 212, 215.
} 
Revolution is that the world must be liberated from U.S. hegemony. Consequently, both ALBA and Iran have focused on subversive warfare, which involves the support of guerilla tactics. Venezuela has been the most supportive, publicly congratulating the work of Hezbollah. ${ }^{37}$

The Iran leadership was glad to ally with Venezuela and develop a special relationship. Nonetheless, the same would not be extended to the other ALBA members. Most important, Cuba did not receive special treatment from Iran, which was not interested in spreading socialism across the world. ${ }^{38}$ Much like has been mentioned in an earlier chapter, Raúl wanted to keep socialism in power. ${ }^{39}$ Therefore, it seems that the Iran relationship does not particularly benefit Cuba since the regime wants to stabilize the special Venezuela relationship and to not jeopardize survival by conspiring with Venezuela to displace the United States.

Iran infiltrated Latin America due to its alliance with Venezuela. Using the Bolivarian government as a middleman, Iran has been able to undermine U.S. hegemony in the region. Iran has funneled weapons and drugs, and shared flight times with Venezuela to coordinate the transport of necessary military technologies. Iranian companies have collaborated with Venezuela to promote illegal trade and undermine U.S. sanctions against the Islamic regime. ${ }^{40}$

In 2007, the Iranian presence in Latin America increased. That year, Iran made official state visits to Nicaragua, Bolivia, and Ecuador, where Iranian officials celebrated the inauguration of their state leaders. In Bolivia, for example, Iran pledged to give over one billion dollars in financial aid during a five-year period. Furthermore, Iran promised to support Bolivia's energy industry. In 2009, after Iran constructed a hospital in Bolivia, citizens were grateful to receive

\footnotetext{
${ }^{37}$ Ibid., 216-217.

${ }^{38}$ Sean Goforth, Axis of Unity: Venezuela, Iran, and the Threat to America (Dules: Potomac Books, 2012), 13-14.

${ }^{39}$ Goforth, Axis of Unity, 14.

${ }^{40}$ Rodil, Martin, “A Venezuelan Platform for Iran's Military Ambitions," in Iran's Strategic Penetration of Latin America, eds. Joseph Humire and Ilan Berman (Lanham: Lexington Books, 2014), 64-67.
} 
treatment from Iranian nurses and doctors. In Achacachi, Bolivia, Iran built a milk factory, which once again was well received by the Bolivian citizens. ${ }^{41}$ In the relationship between Bolivia and Iran, leadership ties were amicable, and the spirit of friendship had spread among the citizens. Consequently, Iran became a strong ally because of its aid.

Nicaragua, however, did not receive favorable treatment from Iran. In 2008, Iran had pledged to provide aid in Monkey Point, Nicaragua. Monkey Point was populated by expatriate Americans who wanted to defend their property from Iran. Consequently, Iran decided to back away from giving aid to Monkey Point. ${ }^{42}$ In Nicaragua, Iran built military bases, which provided little economic compensation to the Ortega government. Additionally, Iran promised to give Nicaragua milk factories, housing, seaport complexes, and energy plants. However, none of these projects were fulfilled. Instead, what Nicaragua received was a hospital. ${ }^{43}$

Ecuador was quite a different case from Cuba, Bolivia, and Nicaragua. To begin, Correa was not an outspoken socialist and was careful not be too closely associated with Venezuela. He disliked some of the actions of the U.S. but was not an adherent of international revolution. Correa also did not want Ecuador to get caught up in the geopolitical struggle and opportunism that Iran practices. ${ }^{44}$ Therefore, an alliance with Iran proved to be problematic for Ecuador.

Iran behaved as an actor based on ideological affinities and then from material benefits with some of the ALBA members. Bolivia was an excellent choice since Morales did not challenge Iran on development projects. Additionally, he gained favor from Iran since Bolivian citizens did not object to being treated by Iranian nurses and doctors. Because Iran provided so many goods and services, most Bolivians did not feel any antagonism toward Iran. Ecuador was

${ }^{41}$ Goforth, Axis of Unity, 47.

${ }^{42}$ Ibid., 52

${ }^{43}$ Ibid., 51.

${ }^{44}$ Ibid., 50. 
different because Correa did not share the reverence for international revolution. The country was too close to the U.S, due to its currency and the fact that Correa wanted to reform neoliberalism in a humane fashion. While Iran is not socialist, the regime shares many of the Latin American Left's ideological premises, including to remove U.S. hegemony and provide extensive welfare.

From a constructivist view, the Venezuela-Iran relationship leans toward material reality. In the relationship, Iran has used Venezuela as a venue to support illegal movement of cargo and people. For Iran, what matters is the ability to gain material influence, and this may be used against the U.S. in a time of emergency. As a result, states such as Nicaragua and Ecuador did not benefit from the Iran relationship because of various factors that impeded agreement. For Nicaragua, the incident at Monkey Point eliminated many possibilities since the presence of American expatriates was a concern for Iran. In the case of Cuba, there was little ideological agreement. Venezuela has been different insofar as it supports Iranian terrorism and illegal trade. For its material concerns, Iran desires support for terrorism, and Venezuela provided an opportunity by not checking incoming cargo. However, Venezuela does not appear to gain much from this deal since Iran has been plagued by international sanctions. Therefore, the relationship was born out of material concern for Iran and continues to be a material concern since the Iranian government wants to develop nuclear weapons and not intense diplomatic ties with ALBA.

\section{Russia: The Dilemma of Trade and Engagement}

Iran was primarily concerned with developing a nuclear program and exporting revolution with its bilateral relationships. Russia's behavior was similar in some ways, especially with the privileging of the bilateral relationship with Venezuela over the other ALBA members. A significant moment in the Russia-Venezuela relationship was in 2008, when both states had a joint naval exercise. Venezuela expressed to the world that the country should be taken seriously. Russia, on the contrary, noted that it wanted to solidify relationships that previously existed during the Soviet period. For the Russian government, this joint exercise was just a continuation of past behavior. That year, Venezuela allowed for the construction of a new Russian airbase in 
its territory. Similar to the joint naval exercise, Russia stated that the base would be used for strictly military purposes..$^{45}$ The relationship is also built on Russia's intent on access to Venezuelan oil. One of the most concerning issues is the negative correlation between democratic freedom and the international price of oil. As the oil prices increase, the presence of democratic freedom decreases. With a high presence of oil, certain states do not have to listen to the demands of their citizens. Additionally, states that have extreme concentrations of oil tend to regress toward authoritarian styles of government. This includes the expansion of the police state and increased domestic intelligence services. In both Russia and Venezuela, their governments continue to keep oil revenue and do not invest heavily in education, entrepreneurship, innovation, and private industry. ${ }^{46}$ Consequently, Venezuela and Russia have a similar system of the government taking money from the oil industry and decreasing democratic freedom.

After the collapse of the Soviet Union in 1991, Russia experienced a democratic transition where Boris Yeltsin became the new president. However, his successor Vladimir Putin created a new system where oligarchs and bureaucrats gained enormous power. Putin also changed his policy between supporting and antagonizing the West based on different circumstances. ${ }^{47}$ Under Putin, Russia has expanded military, energy, technology, and telecommunication ties across Latin America. In the region, the Russian leadership has tailored relations for specific states. Consequently, Russia creates a hierarchy of importance for the different states in the region. More important, Russia has now engaged with various countries in Latin America and the Caribbean that are open for diplomatic, commercial, and military

\footnotetext{
${ }^{45}$ Goforth, Axis of Unity, 86.

${ }^{46}$ Thomas Friedman, “The First Law of Petropolitics,” Foreign Policy 154 (May-June 2006): 31-32, 35.

${ }^{47}$ McNabb, David, Vladimir Putin and Russia's Imperial Revival (Boca Raton: CRC Press, 2016), 5-6.
} 
cooperation. As a result, relations with Cuba and Venezuela are particularly important due to their strategic location to balance the United States and provide an expansion of Russian influence. ${ }^{48}$

From the constructivist perspective, the material reality is that Venezuela has petroleum. As a major producer of this natural resource, great powers, such as Iran and Russia, are drawn to Venezuela and desire to have major political influence in the country. One of the main reasons why Iran and Russia are aggressive to develop to a relationship with Venezuela is to have a physical presence near the U.S. and possibly retaliate if the U.S decides to use military force. Consequently, the idea of a multilateral international system is important for Russia and Iran, and they believe that having a presence in Venezuela might deter further U.S. aggression. Both states have acted in a constructivist manner since they have similar ideological and material interests.

Russia has recently experienced an improved relationship with Cuba. Under Raúl, Cuba initiated a rejuvenation with Russia, when Vladimir Putin, president of Russia, declared that Cuba was a close ally. When Russia occupied Crimea in 2014, Cuba was one of the few countries that supported the move. Russia returned the favor by continuing to condemn the U.S. embargo, and suggesting that it was out of date. Nevertheless, trade between the two states remains low. Bilateral trade in 2012 was recorded at $\$ 270$ million, even though Russia congratulated itself for having various companies operating on the island. ${ }^{49}$ The most significant investment from Russia has been the construction of an international airport near Havana. Russia discussed revamping the Mariel port and increasing cooperation in energy and biotechnology. ${ }^{50}$

Russia decided in 2013 to help revamp the Cuban military. Russia stated that it was not going to provide Cuba state-of-the-art military assets, but only weapons to sustain the island's

\footnotetext{
${ }^{48}$ Marvin Astrada and Félix E. Martín, Russia and Latin America: From Nation-State to Society of States (New York: Palgrave Macmillan, 2013), 13-14, 84-86.

${ }^{49}$ Mervyn Bain, "Russia and Cuba," in Cuban Foreign Policy: Transformation under Raúl Castro, ed. H. Michael Erisman and John Kirk (Lanham: Rowman \& Littlefield, 2018), 237-239.

${ }^{50}$ Bain, "Russia and Cuba," 239-240.
} 
defense. Furthermore, Cuba has been open toward receiving various ships from the Russian navy in Havana over the last few of years. Raúl returned favors when he made an official visit to the Tomb of the Unknown Soldier in Moscow and the Lenin Mausoleum. He gave a speech where he celebrated Soviet assistance to Cuba in the early 1960s to help deter the U.S. and to help solidify the Revolution. He argued that without Russia, the Revolution would have failed. ${ }^{51}$

Rhetoric is a major aspect of the Cuba-Russia relationship. In 2016, when Fidel passed, Russia suggested that it lost a brother and true friend. Russia's leadership further argued that Fidel laid a foundation for the relationship that should be built upon for future generations. This is made evident given that thousands of Russians continue to visit Cuba as tourists each year. In 2001, a record 78,472 Russians visited Cuba, which rose to 86,944 in 2012. As part of the special relationship, Russians do not need visas to travel to Cuba, which has resulted in Russia becoming one of the top ten sources of tourists to the island. Russians are also drawn to the island because Russian is one of the official tourist languages that is provided for state sanctioned tourism. Few countries do this and that is why Russians continue to visit Cuba in large numbers. ${ }^{52}$

Clearly, Russia is interested in maintaining a presence in Latin America to balance U.S. aggression. Consequently, Russia does not desire to assist Venezuela and Cuba because of altruism. This was evidenced when Russia made its first official visit with ALBA leaders in 2008. However, it was out of necessity because that year Russia had declared war against Georgia and needed international support. Nicaragua was the only other country that considered Russia's occupation in parts of Georgia as legal. Moreover, ALBA members that were supportive of Russia often gained economic benefits such as Russian business access. ${ }^{53}$ Nonetheless, Russia

\footnotetext{
${ }^{51}$ Ibid., 240-241.

52 Ibid., 242-243.

${ }^{53}$ Vladimir Rouvinski, "Russia and ALBA: A Marriage of Convenience?" in Decline of the United States Hegemony? A Challenge of ALBA and a New Latin American Integration of the Twenty-First Century, ed. By Bruce Bagley and Magdalena Defort (Lanham: Rowman \& Littlefield, 2015), 307-309.
} 
was not supportive of socialism at this time. In 2008, a journalist asked foreign minister Sergei Lavrov about bringing socialism to Latin America. He responded that if socialism brought people a better life, then he would support the move in the region. ${ }^{54}$ Lavrov shows that Russia's leaders are interested in contesting U.S. hegemony, and not socialism.

Even though Russia claims that ALBA might be an essential trading partner, it neglects aspects of material reality. Russia's largest trading partners are the European Union, China, Ukraine, the U.S., and Japan. The only ALBA member with significant trade to Russia is Ecuador, which accounts for $0.2 \%$ of total Russian trade. Cuba and Nicaragua are at $0.1 \%$ of total Russian trade ${ }^{55}$ Consequently, while Russian leaders might say that Latin America is important for business and trade, the data show that the major Russian interests lie elsewhere. Looking at geography, the countries that are most important to Russia are those at its border, which are its most important trade partners. Ultimately, this is a hindrance to ALBA because Russia is largely preoccupied about various affairs in Europe and Asia, and not Latin America.

Russia, as a constructivist actor, is interested in material reality. Its national interest is building better trade partnerships and displacing U.S. hegemony. Much of this was accomplished by Russia sending business to ALBA members to develop a stronger relationship. However, the larger Russian national interests lie in Europe and Asia. Additionally, in terms of ideology, Russia does not support socialism anymore. Rather than interfere in the internal affairs of ALBA members, Russia leaves the issue of socialism to the individual members.

China: Pragmatic, but not Ideological

Since 1991, China has pursued strategic partnerships with Latin America and the Caribbean. The strategic cooperation encompasses political, technological, scientific, and cultural cooperation. For China, the strategic partnerships must be mutually beneficial, and the host state

\footnotetext{
${ }^{54}$ Rouvinski, "Russia and ALBA: A Marriage of Convenience?" 309.

${ }^{55}$ Ibid., 311.
} 
must be committed to long-term engagement from China. In the strategic partnerships, China values diplomatic support and a partner to help regulate the actions of other states in the international system. ${ }^{56}$ In particular, China decided to ally Venezuela for reasons. Venezuela has high reserves of oil and is geographically close to the United States. Additionally, Venezuela is a strong economic trading partner for China, and the Chávez/Maduro government shares many ideological premises with the Chinese government, especially in its promotion of socialism. ${ }^{57}$

The relationship between China and Venezuela intensified when Chávez became president. Under Chávez, Venezuela signed numerous agreements pertaining to investment, loans, and oil exports to China. In the relationship, several factors must be considered. First, China is interested in accessing natural resources, especially oil. Furthermore, this is extremely important because Venezuela is among the largest states to export oil. Second, China wants a market to expand its businesses, such as Huawei and ZTE. This is noteworthy given that China considers Venezuela to be strategically important. Third, the special relationship with the Venezuelan government is not exploited further since China does not want to harm its relations with the United States. Consequently, while China is careful not to directly confront the U.S., it continues to support the growth of the Bolivarian government's power. Lastly, Venezuela is reprimanded internationally, which pushes the Bolivarian government closer to China. ${ }^{58}$

As a result of trade with China, Venezuela has been able to maintain some degree of political and economic stability. This has been possible since China continues to invest in technical and trade support for Venezuela. Additionally, China has supported the Venezuelan government with foreign direct investment. However, some of the loans had conditionalities, and

\footnotetext{
${ }^{56}$ Xu, Yanran, China's Strategic Partnerships in Latin America: Case Studies of China's Oil Diplomacy in Argentina, Brazil, Mexico, and Venezuela, 1991-2015 (Lanham: Lexington Books, 2017), 2-4.

${ }^{57} \mathrm{Xu}$, China's Strategic Partnerships in Latin America, 13-14.

${ }^{58}$ Ibid, 61-63.
} 
China has used the lure of money to pull Venezuela away from the region. Equally important, China has been using Venezuela as a market for its goods, especially to lessen dependence on the United States. Consequently, a goal for China is to become a greater power in international relations, and one way to do so is to ally with Venezuela and disrupt U.S. power. ${ }^{59}$

Venezuela's partnership with China increased after 2012, when the Bolivarian government recognized China as a market economy. This solidified many of the agreements that were passed between the two states, including measures related to energy and mineral trade. As a result of cooperating with China, Venezuela has received assistance in housing, transportation, and telecommunications. This engagement in Venezuela has allowed China to create a businessfriendly environment for its companies to invest and entrench China's national interests. ${ }^{60}$ However, after Chávez passed in 2013, China has been concerned that the Venezuela government has been spending money recklessly. More important, China is now concerned that it is losing investment in the Venezuela oil industry. This was especially concerning for China after 2014, when the price of oil decreased. Since Venezuela did not diversify the economy beyond oil exports, the Bolivarian government has relied on China for loans. ${ }^{61}$

Under the leadership of Maduro, Venezuela has become dependent on China. However, Venezuela continues to grow in debt since Maduro uses Chinese loans to pay for expenditures. Since the Venezuelan government is heavily involved in the economy, the state has witnessed economic loss due to lack of accountability. Furthermore, the conditionalities of Chinese loans has been cumbersome. However, China is considering Venezuela to be an unreliable partner since Maduro has been unable to gain control of his country's domestic situation. ${ }^{62}$

\footnotetext{
${ }^{59} \mathrm{Xu}$, China's Strategic Partnerships in Latin America, 63.

${ }^{60}$ Ibid., 64-65.

${ }^{61}$ Ibid., 65-67.

${ }^{62}$ Ibid., 72-73.
} 
Returning to a constructivist perspective, ideas seemed to have taken a back seat to material reality. As a result of its domestic needs, China is mostly concerned with obtaining petroleum from Venezuela. Additionally, China also wants to diversify its economic partnerships and decrease dependency on the United States. This accomplishes one of China's main ideational goals, which is to disrupt U.S. power while also not compromising its strategic trade cooperation. While China initially received excellent returns on investment in the Venezuelan economy, it has seen loss due to the fall in the price of oil. This fact has compromised China's position in Venezuela because it now has to send loans to help save its investments from an almost failed state. Under Maduro, the Venezuelan government has continued to spend irresponsibly and with little punishment. Therefore, China is stuck with a sunk cost and a political predicament.

The China-Cuba relationship is unique because while China respects Cuba for practicing socialism, the Chinese leadership is aggressive in noting that the relationship has to be mutually beneficial. Chinese officials have argued that they are not interested in providing free aid to the island and want an agreement that benefits them. According to China, ideology alone will not assist the relationship. However, one significant difference between China and Cuba is that the China leadership is pushing toward a free and transparent economy for foreign investment. As a result, China wants to use free trade zones to showcase that they are open for international business. China considers this necessary to achieve economic growth. Cuba, on the other hand, continues to hold onto socialism. Furthermore, many Chinese people suggest that Cuba's push for keeping socialism is ideal because Cuba continues to fight for equality in a socialist society. ${ }^{63}$

China has helped Cuba to develop through improvements in the Mariel free trade zone and opening a port in Santiago de Cuba. By improving the Mariel free trade zone, China may use the port to access other states in the Caribbean. In an effort to receive more investment from

${ }^{63}$ Adrian H. Hearn and Rafael Hernández, "China and Cuba," in Cuban Foreign Policy: Transformation under Raúl Castro, ed. H. Michael Erisman and John Kirk (Lanham: Rowman \& Littlefield, 2018), 255256. 
China, in 2013 Raúl allowed for international businesses to import goods to the island duty-free. Raúl also gave foreign businesses extensive freedom in the Mariel zone and offered them fiftyyear business contracts. Officials in the Cuban government even argued that the move could allow China's businesses to build goods on the island instead of importing them. China benefited, since its construction companies could now work with little interference from Cuba. ${ }^{64}$

China has been committed to economic reform that provides sustainable development. As a result, there has been a push for privatization, while also emphasizing the government's role in the economy. Cuba, on the other hand, has been slow to allow for private businesses to function in the economy. Additionally, Cuba is aggressive to keep its largely socialist economy intact. China has tilted toward cooperation with the U.S, which has expanded the market economy. Cuba, however, is weary of liberalizing the economy, especially if it leads to domestic dissent.. ${ }^{65}$ In 2013, an election year in Ecuador, China sent $\$ 1.4$ billion to the country, where much of that money was used to support Correa's reelection campaign. While in Ecuador, various Chinese companies have been searching ways to improve the oil industry. However, many of the petroleum projects have been challenged by different rights groups. ${ }^{66}$

China had the least success in Bolivia. To begin, Bolivia has awarded many projects related to lithium to Iran, and China has only been able to complete a few projects. Like Ecuador, China was able to launch a satellite from Bolivia, and Huawei and ZTE have made significant economic investments. Additionally, China has helped Bolivia construct a highway in the Amazon and built a hydroelectric center. China has also built sugar and paper mills in Bolivia. ${ }^{67}$

\footnotetext{
${ }^{64}$ Hearn and Hernández, "China and Cuba,” 259.

65 Ibid., 262-263.

${ }^{66}$ Ellis, R. Evans, "Chinese Engagement with the ALBA countries: A Relationship of Mutual Convenience?, in Decline of the United States Hegemony? A Challenge of ALBA and a New Latin American Integration of the Twenty-First Century, ed. By Bruce Bagley and Magdalena Defort, 351-352.

67 Ellis, "Chinese Engagement with the ALBA countries, 354.
} 
Nicaragua has received the least amount of Chinese investment among the ALBA members. In 2012, China promised Nicaragua that it would build a canal through the country. While the project was officially announced in 2015 , plans have already faltered. The canal would demand between $\$ 50$ billion to $\$ 80$ billion, and funds would come from Chinese banks. ${ }^{68}$

The China-Venezuela alliance initially started strong since Chávez was able to offer vast amounts of oil and profit from the arrangement. Since China needed oil to help run its society and economy, it opted for a military alliance and significant financial investment. Influential leadership made this possible. Venezuela could obtain allies more easily than the other members of ALBA. As a result, Venezuela could gain a powerful ally in China, which would provide much needed financial investment. However, when Maduro assumed the leadership of Venezuela, the relationship turned sour. He was not an influential leader and was preoccupied with paying the debts of Chávez. As a result, China provides financial support to save Maduro.

Chinese leaders have placed emphasis on economic growth and strategic strength. In the case of Cuba, Raúl has made limited economic reforms out of necessity. Raúl fears the erosion of socialism if he allows more freedom in the economy. China, however, has developed a freer market economy that has benefited the ruling elite. While people in China respect that Cuba has maintained socialism, China's leadership does not ignore that Cuba is still economically weak. Following the idea of skills and influential leaders, Cuba experienced little economic growth under Fidel and Raúl, particularly since the 1990s. Both leaders used their positions to maintain power. Cuba, therefore, is not a country that China can easily influence. Other ALBA members such as Bolivia, Ecuador, and Nicaragua did not experience substantial Chinese investment and cooperation, partly because they do not offer the same access to raw materials as Venezuela.

${ }^{68} \mathrm{Ibid}, 355$. 


\section{CHAPTER V Conclusion}

This chapter has discussed the departure of Honduras, Ecuador, and Bolivia from ALBA. In the case of Honduras, influential political actors considered Zelaya a dangerous figure. He was not able to use his skills and position of leadership to persuade the state to ally with ALBA. Zelaya was willing to experiment with socialist policies. However, the members of congress were not willing to support a popular constituent assembly. Congress members believed a push toward socialist policies would hurt their power. Consequently, it was agreed to remove Zelaya.

Correa faced a different situation in Ecuador. The first major aspect to consider is that Correa kept neoliberalism and the U.S. dollar as the official currency. As a result, Ecuador was too embedded in the international economy to commit to the ambitions of ALBA. However, Correa had sympathies with the ALBA leaders. Nonetheless, it was Moreno who decided to leave ALBA since he wanted attention brought to corruption that occurred under Correa. From a constructivist view, Correa was a skilled and influential leader. He was a capitalist and understood that capitalism was beneficial for Ecuador. He also wanted reform to help marginalized groups. Nonetheless, he did not share the same views of socialism. His ideology did not seek or desire revolutionary change. The material reality of neoliberalism and the U.S. dollar currency, alongside the lack of support for revolution, colluded to allow Ecuador to leave.

The last of the countries discussed that left ALBA was Bolivia. Many of the reasons why Bolivia left were brewing for decades. First, many people considered government regulations too abusive. Second, the black market economy was too large. Third, corruption and crime were prominent across the board. Once election fraud was discovered, Morales resigned in shame. Áñez made the strategic change to divorce from ALBA and leftist allies in the region.

Iran is an important state since it provided foreign aid and investment to Venezuela and Bolivia. Regarding Venezuela, Iran used the country as a gateway to Latin America. Furthermore, Iran and Venezuela allowed their citizens to travel visa free. Moreover, Venezuela is also a supporter of multilateralism, which helps Iran with its political agenda. On the other hand, 
Bolivia gained from the active engagement of Iran, who built and supported several hospitals, and a news network. However, Cuba did not benefit from Iran's engagement in the region because the Iranian leadership was not interested in socialist revolution.

In the bilateral relationship with Venezuela, Russia was primarily interested in oil. Yet, Russia's relationship with ALBA is not supportive of socialism. Russia, instead, wants access to raw materials. However, the alliances with its neighbors appear far stronger. More important, Russia has privileged the relationships with its neighbors over those of ALBA.

The last of the extraregional alliances studied was China. The relationship between China and ALBA may be described as lacking ideological congruence. In the case of Cuba, China is mostly concerned with access to the island's market and the Mariel free trade zone. Cuba, on the other hand, wants to keep socialism and tight control of the economy. For Cuba, China is too capitalist and no longer socialist. However, the alliance with Venezuela is different. In Venezuela, China has desired corporate access to Venezuelan oil and business. As result of the domestic challenges since Maduro came into power, Venezuela is now a sunk cost to China.

However, these countries were not as helpful to Cuba and the other members. Cuba wanted to keep socialism as part of its identity, even though Iran, Russia, and China considered it unnecessary. Therefore, ideology was less important for Iran, Russia, and China. These states wanted a material presence to balance the U.S., and the continual push for socialism by Cuba was a hinderance to them. As a result, Cuba received less benefit from Iran, Russia, and China because these states are deeply embedded in a struggle against the U.S. and are interested in economic and military strength as necessary for balancing, and not socialism and revolution. 


\section{CHAPTER 5 CONCLUSION}

This thesis argued that ALBA had two major goals. The first was to build a socialist alternative to neoliberalism, and the second was to foster cooperation among the member states. Furthermore, the thesis suggested that ALBA failed to achieve these goals for three reasons. The founding members, Cuba and Venezuela, experienced a change in leadership that altered the path that ALBA would take. More important, the new leaders of Cuba and Venezuela, Raúl Castro and Nicolás Maduro, were not as committed and persuaded by the goals of ALBA as their predecessors, Fidel Castro and Hugo Chávez. Second, ALBA did not achieve its status as an alternative to neoliberalism. All member states were embedded in the international economy, and only Cuba was the only socialist country in the alliance. Additionally, the different ALBA projects were plagued by ill-defined rules and filled with socialist rhetoric. The third reason was Iran, Russia, and China were pragmatic and did not invest in the vision and dream of ALBA.

To analyze why the organization did not achieve those goals, this thesis used constructivist theory. As a theory of international relations, constructivism privileges the role and impact of ideas on material reality and vice versa. This thesis used two major constructivist works, World of Our Making by Nicolas Onuf and Social Theory of International Politics by Alexander Wendt. To briefly review, Onuf argues that social reality is constructed by the interaction of people. For him, certain knowledge, social events, and history are constructed because people constantly interact. Therefore, construction is endless since people find gaps in knowledge and perception. Rationality comes from society where people make sense of society and their role in it based on material reality. This often comes in the form of rules. He argues that rules are constructed to bind people, where material circumstances have consequences. Therefore, whoever establishes the rules will guide society. Equally important, when leaders create rules and speeches, how they use language matters greatly. When leaders are persuasive and organized, they are better able to facilitate the enforcement of rules and certain action. 
Speech leads to action in several ways. Since social reality is a construction, discourse is in a constant flux. Therefore, if some leaders are able to capture the hearts and minds of the people, then they are described as influential. These leaders are important because they use language that promotes action. Furthermore, influential leaders animate in their speeches and use a variety of techniques to engage the audience. More important, influential leaders have certain skills. For instance, diplomatic skills are important because influential leaders can create their ideas from repeated behavior over time. However, such influential leaders might also have to contend with a growing bureaucracy, which are slow to adapt and change.

The other theoretical work discussed in this thesis was the social theory of international politics by Wendt. He is interested in the relationship between ideas and material reality. He shows that ideas and culture impact the way leaders perceive the international system and behave within it. Therefore, what is important is when leaders act on their beliefs, even if such beliefs are considered problematic. Additionally, while interests might be material or ideational, for numerous reasons people select the goals they want. This is due to socialization, Wendt suggests, where people have values and beliefs that are acted upon.

In socialization, Wendt argues that behavior and institutions, such as an international, economic, or government system are built by ideas. When using ideas as a mode of analysis, it is possible to locate rules, norms, beliefs, and values in society. These factors guide behavior, and if a scholar were to divorce ideas from action, it would be difficult to decide which actions were motivated by certain ideas, and which were not. For Wendt, this is critical because many international relations theories, such as realism and neorealism, do not give enough credit to the roles of ideas in international relations. ${ }^{1}$ Constructivism, hence, fills that void.

Furthermore, in socialization, scholars will be able to give significant consideration to certain ideas about international relations. Wendt, of course, refers to the international system, or

\footnotetext{
${ }^{1}$ Wendt, Social Theory of International Politics, 101.
} 
other guiding ideas such as international revolution or international socialism. These ideas are important because they guide society, and hence people's actions. More important, socialization changes state action. ${ }^{2}$ Consequently, a state that is neoliberal will act in the international system differently than a state that is socialist. A state that is ruled by authoritarian, therefore, will behave differently than a republic because the rules and norms that both states and leaders are guided by are different. From the analysis provided by Wendt, the social situation matters because each state has a unique experience and system of economy and government. As a result, people in those states behave differently because of the norms and rules that guide their society.

In international relations, some leaders want to fight for a system that protects states from aggressive imperialist powers. Consequently, if some leaders come from cultures and beliefs systems that privilege collective security and the community, they are more likely to support such expansive foreign policies. Moreover, such foreign policy is essential because leaders promote and enforce laws domestically that adhere to similar values. As a result, the culture, beliefs, and values of a leader have great significance and cannot be isolated from international relations or other variables. Hence, ideas return as at the center of analysis because they provide a unique motivation and limitation that is different for leaders and their material circumstances.

Wendt further argues that knowledge in international relations is divided between private knowledge and culture. In private knowledge, leaders have beliefs and ideas that is usually drawn from ideological or domestic concerns. Culture is different because leaders interact with each other and share and debate different rules, norms, ideas, beliefs, and values. Therefore, certain ideas are debated because they have significance and consequences for different people.

The largest limitation to my thesis is that I selected to not use a major theory. In particular, neorealism offers a great challenge because it highlights that in unipolar system, states are in a constant struggle for hegemony and war looms large. While this is accurate, my thesis is

\footnotetext{
${ }^{2}$ Ibid, 102.
} 
different because it gives significant attention to ideology and material reality, and their interdependence. Neorealism does not give attention to ideology or the impact of material reality. Additionally, the most important factors considered in this thesis is the change of leadership in the ALBA members and the poor implementation of the ALBA programs. These two issues are significant because the Raúl and Maduro leadership were less persuaded by the ALBA goals. Additionally, the exit of Honduras, Ecuador, and Bolivia is attributed to the change of leadership. Moreover, the poor implementation of the goals of the TCP, SUCRE, and Petrocaribe showcases how the ideas of socialism were incongruent with the material reality of the ALBA members because of their different economic development and inability to cooperate.

Chapter Two of this thesis provided an analysis of the foreign policy of Raúl Castro and Nicolás Maduro. As the evidence shows, Raúl behaved as an influential leader who wanted to defend socialism on the island. As a result, while Raúl shared sympathies with Venezuela, he did not want Cuba to depend on it. Therefore, he expanded Cuba's alliance system and advocated that Cuba did not focus all its foreign policy on Venezuela. Consequently, Raúl allied with the U.S., Mexico, and other states in Latin America and the Caribbean. While expanding his alliances, he kept socialism. Therefore, he maintained his conviction to ideology while also recognizing that the material reality needed to change in order for the socialist government to survive.

The case of Maduro was different. He tried to ride the coattail of Chávez. Maduro also had to face the material reality that he was selected by the Castro brothers in a compromise, and without the support of the Venezuelan people. Moreover, he had to contend with the consequences of the Chávez era, especially in the economy. As a result, he was compelled to confront the country's issues and had little time to help improve the Venezuela economy.

Chapter Three provided an overview of socialist policies of Fidel and Chávez. The chapter also discussed the TCP, SUCRE, and Petrocaribe. A major takeaway was that Fidel and Chávez took the ALBA project personally and were convinced by socialism. They were willing 
to change the material reality of Cuba and Venezuela to achieve socialism. However, some of the projects from ALBA did not achieve a socialism or cooperation.

The TCP was problematic for various reasons. First, many of the TCP agreements were bilateral. Second, many members were not economically competitive and did not have the natural and human resources to compete. Lastly, ALBA members were also a part of the WTO and many TCP regulations simply conflicted with those of the WTO. Overall, the TCP agreements did not allow for sustainable and comprehensive economic growth in the member states.

SUCRE was another problematic ALBA project. SUCRE faced two major issues. The first issue was that many of the ALBA members failed to diversify their economies. Second, SUCRE included a currency, called the sucre, that was not fully accepted by all ALBA members. From a constructivist perspective, the SUCRE was plagued with empty rhetoric about socialism. In the material reality, trade between ALBA members was limited and many members wanted to use the U.S. dollar as the currency of exchange, and not the sucre. This defeated cooperation.

A third program that was discussed was Petrocaribe. However, this program was even more problematic than the two previous ones because not all members of Petrocaribe are members of ALBA. Here, Venezuela was mostly the main leader, and Venezuela used Petrocaribe to gain more influence in Latin America and the Caribbean. However, many members of Petrocaribe did not join ALBA since they considered socialism to be dangerous.

Ultimately, ALBA failed to create a viable socialist alternative since the initiatives did not allow the members to diversify their economies and become competitive against neoliberal states. Furthermore, ALBA could not escape from the reality that the United States dominates the international economy. Moreover, many ALBA members considered that it was easier to use the mechanisms already established by the U.S. instead of creating a new economic order difficult to replicate in other areas of the world. Therefore, the ideology of socialism did not match the reality that internationally, countries need to diversify and grow in order to survive. 
Chapter Four provided an analysis of why some members of ALBA departed from the organization. Additionally, the chapter discussed some of the extraregional alliances with Iran, Russia, and China, and the issues raised by those alliances. Honduras was the first member to leave ALBA. From the constructivist point of view, former president Manuel Zelaya was not able to convince the Honduran congress of his socialist aspirations. Additionally, from a materialist perspective, the congress had a lot to lose from socialism and an alliance with Venezuela. The case of Ecuador was different since the country was materially embedded in neoliberalism and Correa was not fully convinced of socialism. Rafael Correa was invested in keeping Ecuador economically competitive, especially vis-à-vis Venezuela. Additionally, he desired to reform capitalism and not replace it with socialism. However, his successor, Lenín Moreno, was chiefly concerned with domestic issues and considered ALBA a detriment. The material reality was that Ecuador's interests, including the use of the U.S. as an official currency, simply did not match with the socialist agenda promoted by ALBA and its members. Therefore, the exit of Ecuador was a natural result of the country's lack of support for socialism and revolution.

Bolivia was in a different situation from Honduras and Ecuador. This was because Evo Morales did not attend to solving deep societal issues. Bolivia was plagued by the black market economy and massive corruption and fraud. These issues came to light once the country was not making much income from natural resources. Alongside election fraud, voters realized that Morales would make situations worse. His successor, Jeanine Áñez, seeing material reality and using influence as the new leader, took the opportunity to break ties with ALBA as a political statement. Áñez was probably a more influential leader when compared to Moreno because she decided that Bolivia needed a strategic change in policy. This cuts across both ideology and material reality since her politics are different from Morales. By removing Bolivia from ALBA, she became determined that socialist aspirations were not in the future of Bolivia.

ALBA was also plagued by shifting alliances with Iran, Russia, and China. The relationship between Iran and ALBA was mostly conducted on a bilateral basis. As a result, Iran 
gave preferential treatment toward members that could assist the Middle Eastern country with developing nuclear weapons. Consequently, Iran focused on ALBA members such as Venezuela and Bolivia since they provided needed raw materials, such as minerals. In Venezuela, this was important since the Bolivarian government gained favor by allowing travel to and from Iran without visas. Bolivia, however, had the benefit of Iran providing and supplying hospitals with Iranian staff, and creating a local television station. These actions helped Iran attract followers in ALBA. Other members, such as Nicaragua and Ecuador, were not assisted by Iran because they did not appear to support Iran's grand strategy of fomenting an international revolution. Moreover, the material reality in Nicaragua and Ecuador conflicted with Iran's goals. For Nicaragua, it was the presence of American expatriates, and for Ecuador, it was its strong neoliberal economy and its leadership being reluctant to support international revolution.

Russia was a different case from Iran, especially since natural resource access was not a major concern. However, Russia appeared to expand trade with ALBA because it did not want to be limited to its neighbors in Europe and Asia. Yet, Russia barely expanded its alliance system with Cuba, for example, by seeking financial investment and not an expanded presence on the island. However, Russia still considers relations with Europe and Asia more important.

The last of the extraregional actors studied in this thesis was China. It was interesting case due to the fact that China privileges financial and investment relationships that strengthen its relationship over the United States. As a pragmatic actor, China sought to diversify its international relationships to lessen its dependence on the U.S. in the international economy. However, the U.S. relationship has limited China since it is careful to not have too much engagement with ALBA. Nonetheless, the bilateral relationships with ALBA have not worked well for China. In particular, Venezuela has failed to pay its debts, and China has invested more money to recuperate lost money from previous ventures. Additionally, Chinese plans to build a canal in Nicaragua have disappeared, and China has not released the details for its decision. 
Constructivism is helpful to understand why ALBA failed to achieve its main goals since the organization could not reconcile the differences between material reality and ideology. Fidel and Chávez created a socialist project that was dependent on their leadership to survive. As a result of their leadership, ALBA was able to sustain the trade of internationalists for oil.

However, once new leadership emerged in Cuba and Venezuela, the material reality began to change. With Raúl, Cuba began a new foreign policy that stressed new relationships with other countries in the region. Moreover, Raúl made note that Cuba was staunchly socialist but that the island new relationships to avoid total dependency on Venezuela. As a result, Raúl may be perceived as an influential leader because he was pragmatic, and he recognized that the material island of Cuba had to be improved. Therefore, an expansion of alliances was necessary.

In Venezuela, Maduro was immediately the target of criticism because he was not chosen by the Venezuelan people. He rode the coattail of Chávez but did not expand and improve the existing social programs. Additionally, he was careless with the finances of the country, and did not improve the bureaucracy of the oil industry. Consequently, Maduro faced a crisis of legitimacy. He was not influential because he ignored the needs of Venezuelans.

The other factor considered in this thesis was the failure of ALBA to create a socialist alternative to neoliberalism. This was largely due to the poorly established programs. Programs such as the TCP, SUCRE, and Petrocaribe suffered from vague rules and regulations. They also lacked measures to promote sustainable economic development and growth. More important, these programs offered little incentive for ALBA members to participate and receive benefits.

The last of the factors considered were the alliances from Iran, Russia, and China that Venezuela welcomed. These alliances were problematic because they were bilateral. Neither Iran, Russia, nor China seemed interested in promoting socialism. Instead, each saw an alliance with ALBA members as an opportunity to access to Venezuelan oil. ALBA members received different treatment based on their capacity to satisfy the needs of either Iran, Russian, or China. 


\section{BIBLIOGRPAHY}

Anderson, Tim. "Chávez and American Integration." In Democracy, Revolution, and Geopolitics in Latin America: Venezuela and the International Politics of Discontent, edited by Luis Fernando Angosto-Ferrández, 13-46.London and New York: Routledge, 2014.

Angosto-Ferrández, Luis Fernando. "Ordering Discontent: Domestic and International Dynamics of the Bolivarian Revolution." In Democracy, Revolution, and Geopolitics in Latin America: Venezuela and the International Politics of Discontent, edited by Luis Fernando Angosto-Ferrández, 177-94. London and New York: Routledge, 2014.

Aponte-García, Maribel. "The New Strategic Regionalism in the ALBA-TCP: Alternatives to the Food and Energy Crises." In Counter-Globalization and Socialism in the $21^{\text {st }}$ Century: The Bolivarian Alliance for the Peoples of Our America, edited by Thomas Muhr, 11937. London: Routledge, 2013.

Astrada, Marvin, and Félix E. Martín, Russia and Latin America: From Nation-State to Society of States. New York: Palgrave Macmillan, 2013.

Azicri, Max. "The Castro-Chávez Alliance.” Latin American Perspectives36, no. 1 (January 2009): 99-110.

Azicri, Max. "The Cuba-Venezuela Alliance and Its Continental Impact." In Cuba in a Global Context: International Relations, Internationalism, and Transnationalism, edited by Catherine Krull, 127-43. Gainesville: University Press of Florida, 2014.

Bain, Mervyn. "Russia and Cuba." In Cuban Foreign Policy: Transformation under Raúl Castro, edited by H. Michael Erisman and John Kirk, 237-53. Lanham: Rowman \& Littlefield, 2018 .

Benzi, Danielle, and Ximena Zapata. "Good-Bye Che? Scope, Identity, and Change in Cuba's South-South Cooperation." In South-South Cooperation Beyond the Myths: Rising Donors, New Aid Practices? edited by Isaline Bergamaschi, Phoebe Moore, and Arlene B. Tickner, 79-106. London: Palgrave Macmillan, 2017.

Bohoslavsky, Juan Pablo. "Development and Human Rights in Bolivia: Advances, Contradictions, and Challenges.” Latin American Policy 11, no.1 (2020): 126-47.

Borbón, Josette Altmann. “ALBA: Ideology Overcomes Integration?" In Decline of the United States Hegemony? A Challenge of ALBA and a New Latin American Integration of the Twenty-First Century, edited by Bruce Bagley and Magdalena Defort, 67-96. Lanham: Lexington Books, 2015. 
Berman, Ilan. "What Iran wants in the Americas." In Iran's Strategic Penetration of Latin America, edited by Joseph Humire and Ilan Berman, 1-9. Lanham: Lexington Books, 2014.

Briceño-Ruiz, José. "Venezuela and South-South Cooperation: Solidarity or Realpolitik?." In South-South Cooperation Beyond the Myths: Rising Donors, New Aid Practices?, edited by Isaline Bergamaschi, Phoebe Moore, and Arlene B. Tickner, 173-96. London: Palgrave Macmillan, 2017.

Brower, Steve. Revolutionary Doctors: How Venezuela and Cuba are changing the World's Conception of Health Care. New York: Monthly Review Press, 2011.

Chacón, Eduardo. "Twenty-first century socialism: a political and pedagogical act: Some keys to understand." In Counter-Globalization and Socialism in the $21{ }^{\text {st }}$ Century, edited Thomas Muhr, 33-45. New York: Routledge, 2013.

Cooper, Amy. State of Health: Pleasure and Politics in Venezuelan Health Care under Chávez. Oakland: University of California Press, 2019.

Corrales, Javier and Michael Penfold. Dragon in the Tropics: The Legacy of Hugo Chavez. Washington, DC: Brookings Institution Press, 2015.

Corrales, Javier and Carlos Romero. U.S.-Venezuela Relations Since the 1990s: Coping with Midlevel Security Threats. New York: Routledge, 2013.

Cusack, Asa. Venezuela, ALBA, and the Limits of Postneoliberal Regionalism in Latin America and the Caribbean. London: Palgrave, 2019.

de la Torre, Carlos. "A Populist International?: ALBA's Democratic and Autocratic Promotion." SAIS Review of International Affairs vol. 37, no.1 (Winter-Spring 2017): 83-93.

Ellis, R. Evan. "Chinese Engagement with the ALBA Countries: A Relationship of Mutual Convenience? In Decline of the United States Hegemony? A Challenge of ALBA and a New Latin American Integration of the Twenty-First Century, ed. By Bruce Bagley and Magdalena Defort, 345-68. Lanham: Rowman \& Littlefield, 2015.

Friedman, Thomas. "The First Law of Petropolitics." Foreign Policy 154 (May-June 2006): 2836.

Furtado, João Marcello et al. "Is Misión Milagro an effective program to prevent blindness in Latin America?” Arq Bras Oftalmol 73, 5 (August 2010): 397-8. 
Goforth, Sean. Axis of Unity: Venezuela, Iran, and the Threat to America. Dules: Potomac Books, 2012.

Hearn, Adrian H. and Rafael Hernández, "China and Cuba," in Cuban Foreign Policy: Transformation under Raúl Castro, edited by H. Michael Eirsman and John Kirk, 255-67. Lanham: Rowman \& Littlefield, 2018.

Hirst, Joel and Christopher Sabatini. "A Guide to ALBA: What is the Bolivarian Alternative to the Americas and What Does It Do?" In Decline of the United States Hegemony? A Challenge of ALBA and a New Latin American Integration of the Twenty-First Century, edited by Bruce Bagley and Magdalena Defort, 1-11. Lanham: Lexington Books, 2015.

Hirst, Joel. The ALBA: Inside Venezuela's Bolivarian Alliance. Miami: InterAmerican Institute for Democracy, 2012)

Humire, Joseph. "Preface Iran's Intrusion: An Overview." In Iran's Strategic Penetration of Latin America, edited by Joseph Humire and Ilan Berman, xv-xviii. Lanham: Lexington Books, 2014.

Humphrey, Michael and Estrela Valverde. "Hope and Fear in Venezuelan Democracy: Violence, Citizen Insecurity, and Competing Neoliberal and Socialist Urban Imaginaries." In Democracy, Revolution, and Geopolitics in Latin America: Venezuela and the International Politics of Discontent, edited by Luis Fernando Angosto- Ferrández, 14776. New York: Routledge, 2015.

Kirk, John. Healthcare Without Borders: Understanding Cuban Medical Internationalism. Gainesville: University of Florida Press, 2015.

Kirk, John. "Historical Introduction to Foreign Policy under Raul Castro." In Cuban Foreign Policy: Transformation under Raul Castro, edited by H. Michael Eirsman and John M. Kirk, 1-21. Lanham: Rowan \& Littlefield, 2018.

Lehocuq, Fabrice. "Bolivia’s Citizen Revolt," Journal of Democracy 31, no. 3 (July 2020): 13044.

McNabb, David. Vladimir Putin and Russia's Imperial Revival. Boca Raton: CRC Press, 2016.

Mearsheimer, John. The Tragedy of Great Power Politics. New York, London: W.W. Norton \& Company, 2001.

Muhr, Thomas. Venezuela and the ALBA: Counter-Hegemony, Geographies of Integration and Development, and Higher Education for All. Saarbucken: Verlag Dr. Muller, 2011. 
Muñoz-Pogossian, Betilde. Electoral Rules and The Transformation of Bolivian Politics: The Rise of Evo Morales. New York: Palgrave Macmillan, 2008.

Onuf, Nicolas. World of Our Making: Rules and Rule in Social Theory and International Relations. Columbia: University of South Carolina Press, 1989.

Rodil, Martin. “A Venezuelan Platform for Iran's Military Ambitions.” In Iran's Strategic Penetration of Latin America, edited by Joseph M. Humire and Ilan Berman, 63-9. London: Lexington Books, 2014.

Rojas, Rafael. "Ecuador: Lenin Moreno, the Troubling Successor to Rafael Correa." Havana Times. Accessed August 2, 2020. https://havanatimes.org/news/ecuador-lenin-morenothe-troubling-successor-to-rafael-correa/.

Romero, Carlos. "Cuba and Venezuela.” In Cuban Foreign Policy: Transformation under Raul Castro, ed. H. Michael Erisman and John M. Kirk, 209-224. Lanham: Rowan \& Littlefield, 2018.

Romero, Carlos and Grecia Benayas. "Venezuela: el ocaso de una democracia." Revista Mexicana de Ciencias Políticas y Sociales, no. 233 (February 2018): 285-306.

Romero, Carlos, and Victor Mijares. "From Chavez to Maduro: Continuity and Change in Venezuelan Foreign Policy." Contexto Internacional vol. 38, no. 1 (January/April 2016): 165-201.

Rosales, Antulio and Manuel Cerezal. "The SUCRE and the ALBA-TCP monetary union: responses from the South to the global crisis." In Counter-Globalization and Socialism in the $21^{\text {st }}$ Century: The Bolivarian Alliance for the Peoples of Our America, edited by Thomas Muhr, 138-154. London: Routledge, 2013.

Rouvinski, Vladimir. "Russia and ALBA: A Marriage of Convenience?" In Decline of the United States Hegemony? A Challenge of ALBA and a New Latin American Integration of the Twenty-First Century, edited by Bruce Bagley and Magdalena Defort, 299-319. Lanham: Rowman \& Littlefield, 2015.

Selcuk, Orcun. "Strong presidents and weak institutions: populism in Turkey, Venezuela, and Ecuador." Southeast European and Black Sea Studies 16, no. 4 (September 2016): 571 589.

Serbin, Andres. "Cuba and Latin America and the Caribbean." In Cuban Foreign Policy: Transformation under Raul Castro, ed. H. Michael Eirsman and John M. Kirk, 77-94. Lanham: Rowan \& Littlefield, 2018. 
Wendt, Alexander. Social Theory of International Politics. Cambridge: Cambridge University Press, 1999.

Xinhua. "Bolivia withdraws from ALBA, recalls most of its ambassadors." Accessed August 5, 2020. http://www.xinhuanet.com/english/2019-11/16/c_138559166.htm.

Xu, Yanran. China's Strategic Partnerships in Latin America: Case Studies of China's Oil Diplomacy in Argentina, Brazil, Mexico, and Venezuela, 1991-2015. Lanham: Lexington Books 2017.

Yaffe, Helen. "Cuban Socialism: inspiration to the ALBA-TCP." In Counter-Globalization and Socialism in the $21^{\text {st }}$ Century, edited by Thomas Muhr, 101-8. New York: Routledge, 2013. 